\title{
Pilot GWAS of caries in African-Americans shows genetic heterogeneity
}

\author{
E. Orlova ${ }^{1+}{ }^{1}$, J. C. Carlson ${ }^{2 \dagger}$, M. K. Lee ${ }^{3 \dagger}$, E. Feingold ${ }^{1,2,3}$, D. W. McNeil ${ }^{4}$, R. J. Crout ${ }^{5}$, R. J. Weyant ${ }^{6}$, \\ M. L. Marazita ${ }^{1,3,7,8}$ and J. R. Shaffer ${ }^{1,3^{*}}$
}

\begin{abstract}
Background: Dental caries is the most common chronic disease in the US and disproportionately affects racial/ ethnic minorities. Caries is heritable, and though genetic heterogeneity exists between ancestries for a substantial portion of loci associated with complex disease, a genome-wide association study (GWAS) of caries specifically in African Americans has not been performed previously.

Methods: We performed exploratory GWAS of dental caries in 109 African American adults (age > 18) and 96 children (age 3-12) from the Center for Oral Health Research in Appalachia (COHRA1 cohort). Caries phenotypes (DMFS, DMFT, dft, and dfs indices) assessed by dental exams were tested for association with 5 million genotyped or imputed single nucleotide polymorphisms (SNPs), separately in the two age groups. The GWAS was performed using linear regression with adjustment for age, sex, and two principal components of ancestry. A maximum of 1 million adaptive permutations were run to determine empirical significance.
\end{abstract}

Results: No loci met the threshold for genome-wide significance, though some of the strongest signals were near genes previously implicated in caries such as antimicrobial peptide DEFB1 (rs2515501; $p=4.54 \times 10^{-6}$ ) and TUFT1 ( rs1 1805632; $p=5.15 \times 10^{-6}$ ). Effect estimates of lead SNPs at suggestive loci were compared between African Americans and Caucasians (adults $N=918$; children $N=983$ ). Significant $\left(p<5 \times 10^{-8}\right)$ genetic heterogeneity for caries risk was found between racial groups for $50 \%$ of the suggestive loci in children, and $12-18 \%$ of the suggestive loci in adults.

Conclusions: The genetic heterogeneity results suggest that there may be differences in the contributions of genetic variants to caries across racial groups, and highlight the critical need for the inclusion of minorities in subsequent and larger genetic studies of caries in order to meet the goals of precision medicine and to reduce oral health disparities.

Keywords: Child, Adult, Genetic predisposition to disease, Humans, Dentistry, Public health, Healthcare disparities*

\section{Background}

Dental caries is a complex disease influenced by genetic and environmental factors, including diet, oral hygiene, oral bacteria such as Streptococcus mutans, tooth morphology and placement, the composition and flow rate of saliva, fluoride exposure, and access to oral health care [1-4]. Genetic determinants of caries differ, in part, based on tooth surface and tooth type (primary versus permanent)

\footnotetext{
* Correspondence: john.r.shaffer@pitt.edu

${ }^{\dagger}$ E. Orlova, J. C. Carlson and M. K. Lee contributed equally to this work.

'Department of Human Genetics, Pittsburgh, USA

${ }^{3}$ Center for Craniofacial and Dental Genetics, Dept. of Oral Biology, School of Dental Medicine, University of Pittsburgh, Pittsburgh, PA, USA

Full list of author information is available at the end of the article
}

[5, 6]. Etiological mechanisms can additionally involve gene-by-sex and gene-by-environment interactions $[7,8]$.

According to the National Health and Nutrition Examination Survey (NHANES), caries affects the majority of children (i.e., $23 \%$ by age 5 years, $56 \%$ by age 8 , $67 \%$ by age 19$)$, and adults (91\%) and is the most common chronic disease in the United States [9-11]. Lack of treatment leads to serious co-morbidities that greatly impair quality of life [9].

Although caries has declined in the United States since the mid-twentieth century, the caries rate in young children has increased in recent years, and disparities persist between racial/ethnic, demographic, and socioeconomic

(c) The Author(s). 2019 Open Access This article is distributed under the terms of the Creative Commons Attribution 4.0 International License (http://creativecommons.org/licenses/by/4.0/), which permits unrestricted use, distribution, and reproduction in any medium, provided you give appropriate credit to the original author(s) and the source, provide a link to the Creative Commons license, and indicate if changes were made. The Creative Commons Public Domain Dedication waiver (http://creativecommons.org/publicdomain/zero/1.0/) applies to the data made available in this article, unless otherwise stated. 
groups [10-12]. Caries prevalence in primary teeth is $42 \%$ higher in non-Hispanic black children compared with non-Hispanic Caucasian children. Non-Hispanic black children have double the rate of untreated tooth decay in primary teeth compared to non-Hispanic Caucasian children [11], and among adults, non-Hispanic blacks have nearly double the rate of untreated decayed teeth (42\%) of non-Hispanic Caucasians (22\%) [10].

Some disparity is explained by sociocultural differences between racial groups. African Americans are less likely to have access to and utilize oral health care [13, 14]. Other factors include differences in caretaker fatalism and oral health education [15], socioeconomic status, and transmission of cariogenic bacteria [16]. Genetic differences in caries predisposition are known: the $2 \%$ of African American children with localized juvenile periodontitis - a disease more common in African Americans - have fewer carious teeth than others, likely due to a variant in the gene encoding a protective component of saliva [17]. Other differences include those in immunity genes and propensity toward cariogenic oral flora [18]. While inter-racial genetic differences influence dental features [19], there is a dearth of studies on the role of genetics in differences in dentition across racial and ethnic groups.

Although dental caries is estimated to be $30-50 \%$ heritable $[1,5,6,20]$, few specific caries-related genes have been discovered, with the majority of these identified in Caucasians [21]. Yet, it is known that some complex diseases exhibit differences in their predominant genetic architecture across races [22-24]. Genetic markers for disease vary in frequency between races, and the effect sizes of the genetic variants can display large heterogeneity [25]. Indeed, up to $25 \%$ of GWAS tagSNPs show effect heterogeneity by ancestry [26]. Thus it is possible that there are different genetic risk factors for caries operating between races, or that the effects of risk variants are dissimilar. In spite of this, adequate information is lacking regarding the disease process in vulnerable groups such as racial/ethnic minorities; in particular, few studies have focused on the oral health of African Americans [12]. Genome-wide association studies (GWAS) of dental caries in African American samples have not been performed, and although African-Americans are a large US minority group, little work has been done to understand their dental genetics. In this study, we describe a pilot caries GWAS in African American children and adults to generate hypotheses about the genetics of dental caries in African Americans. We consider primary and permanent dentition separately because previously work has estimated that only $18 \%$ of covariation in primary vs permanent tooth caries is due to common genetic factors [6]. Furthermore, we compare the GWAS scans in African Americans to analogous analyses in Caucasian children and adults to determine whether there is heterogeneity present between the two racial groups.

\section{Methods}

\section{Study sample}

One hundred nine African American adults (aged $>18$ years) and 96 African American children (3-12 years) were recruited through the Center for Oral Health Research in Appalachia (COHRA, cohort COHRA1), a joint study of the University of Pittsburgh and West Virginia University [27]. Briefly, all participants provided consent or assent with written parental informed consent, in accordance with the Institutional Review Board policies of the University of Pittsburgh and West Virginia University. Two clinical examination sites were located in Pennsylvania and four in West Virginia. Admixed African ancestry was verified using Principal Component Analysis (PCA) with respect to HapMap controls from Europe, Asia, Africa, and Central/South America. Participants were genotyped for approximately 550,000 single nucleotide polymorphisms (SNPs) using the Illumina Human610-Quad Beadchip (Illumina, Inc., San Diego, CA). Genetic data were rigorously cleaned and quality-checked as previously described [28], and imputed to the 1000 Genomes Project (June 2011) phase 1 reference panel using SHAPEIT (for pre-phasing) [29] and IMPUTE2 [30]. SNPs were filtered for INFO score $>0.5$, and MAF $>$ $5 \%$ (separately for each age group). SNPs were not filtered for HWE due to the admixed nature of the African American population. Quality filters included participant call rates $>90 \%$ and SNP call rates $>99 \%$. Approximately 4.9 million SNPs passed quality control and were included in the GWASs. Identical analyses were performed in COHRA-recruited cohorts of 918 Caucasian adults and 983 children (results for these cohorts have been previously published) $[28,31]$. The same filters were used in Caucasians (separately for each age group) along with a filter for HWE $\left(p\right.$-value $\left.>10^{-4}\right)$. STROBE guidelines were followed for this observational study.

\section{Quantitative caries phenotypes}

Ascertainment of caries status was conducted with a dental explorer by either a licensed dentist or a dental hygienist. The assessments were done in exam rooms with a dental chair and dental examination light on dried teeth, and were mutually calibrated at the start of the study and several times over the course of data collection via a review of data collection techniques followed by reliability testing [27]. Inter- and intra-rater reliability of caries assessments was high [27]. From these assessments, the following caries phenotypes were generated: the DMFS index (Decayed, Missing, and Filled Tooth Surfaces) and DMFT index (Decayed, Missing, and Filled Teeth) in adults, and the dfs index (decayed and filled deciduous tooth surfaces) and dft index (decayed, and filled deciduous teeth) in children. These caries indices represent the count of affected tooth surfaces or teeth, in accordance with the World Health Organization DMFS/dfs or DMFT/dft scales [32] and established dental 
caries research protocols [33, 34]. For 31 of the 96 children in the African American pediatric cohort with mixed dentition, and 378 of 983 children in the Caucasian pediatric cohort with mixed dentition, both DMFS/DMFT and dfs/dft indices were scored at the time of the assessment. For the purposes of this study only $\mathrm{dfs} / \mathrm{dft}$ measures were tested for association in the pediatric cohorts. White spots were included in the DMFS/DMFT and $\mathrm{dfs} / \mathrm{dft}$ counts because their inclusion has been shown to increase caries heritability estimates and thus improve power to detect association in gene mapping [6].

\section{Statistical model}

The GWASs were performed separately in adults (for DMFT and DMFS) and children (for dft and dfs) using linear regression while adjusting for age, sex, and two principal components of ancestry in PLINK v1.9 [35]. Statistical significance was determined using adaptive imputation with a maximum number of 1,000,000 permutations per SNP as implemented in PLINK. $P$-value thresholds incorporated the burden of multiple testing: genome-wide significance was defined as $p$-value less than $5 \times 10^{-8}$ and suggestive significance as p-value less than $5 \times 10^{-6}$. Results were visualized in Manhattan plots using R (v3.2.0) [36].

\section{Results annotation and comparison with Caucasian caries GWASs}

Genes within $500 \mathrm{~kb}$ of the top associated SNP in each locus were queried for corroborating biological connections to dental caries in public databases, including OMIM, PubMed, and ClinVar. In addition, GREAT [37] was used to assess the functions of cis-regulatory regions of the associated loci using default parameters.

Heterogeneity in effect sizes between the GWAS results of African Americans and Caucasians were compared via Cochran's $Q$ statistic. The effect sizes for the lead SNPs at suggestive ( $p$-value $\leq 5 \times 10^{-6}$ ) loci observed in African Americans were compared with the effect sizes of the same SNPs in Caucasians, if present. Not all suggestively-associated lead SNPs in African Americans were tested for heterogeneity because MAF and quality controls filters yielded different sets of SNPs retained for African Americans and Caucasians. Specifically, the numbers of loci tested for heterogeneity were 17 of 25 for DMFT, 11 of 12 for DMFS, 20 of 26 for dft, and 12 of 18 for dfs. The genome-wide significance threshold for heterogeneity tests was $p$-value $\leq 5 \times 10^{-8}$.

\section{Results}

Four GWASs of indices of dental caries were performed: DMFS and DMFT in 109 African American adults, and dfs and dft in 96 African American children. Cohort demographics are shown in Table 1. The GWAS in African Americans did not yield associations at genome-wide significance ( $p$-value $\leq 5 \times 10^{-8}$ ) for any phenotype (Fig. 1), while several loci with potential roles in caries etiology were associated at suggestive significance ( $\mathrm{p}$-value $\leq 5 \times 10^{-6}$ ).

\section{GWASs of caries in the permanent dentition in African Americans}

The GWAS of DMFT yielded 94 suggestive (p-value $\leq 5 \times$ $10^{-6}$ ) SNPs across 25 distinct loci. The GWAS of DMFS yielded 23 suggestive SNPs across 11 distinct loci. These loci and corroborating evidence for nearby genes are listed in Table 2 (DMFT) and Table 3 (DMFS). Many of the top loci for the two phenotypes overlapped (rs6947348, rs12171500, chr3:194035416, rs12488352, rs1003652). GREAT regulatory analysis results are available in the Appendix.

\section{GWASs of caries in the primary dentition in African Americans}

The dft GWAS yielded 46 suggestive SNPs across 17 distinct loci. The dfs GWAS yielded 32 suggestive SNPs across 17 distinct loci. Two loci overlapped between $\mathrm{dfs}$ and $\mathrm{dft}$ (rs2012033 and rs74574927/rs78777602). One notable suggestive locus, indicated by rs2515501 ( $p$-value $4.54 \times 10^{-6}$ ), harbors antimicrobial peptide $D E F B 1$. Gene annotations for the suggestive loci ( $\mathrm{p}$-value $\leq 5 \times 10^{-6}$ ) are listed in Table 4 (dft) and Table 5 (dfs). GREAT regulatory analysis results are available in the Appendix.

\section{Comparison with Caucasian caries GWAS}

Results of the tests for heterogeneity between African Americans and Caucasians are listed in Table 6. Significant ( $\mathrm{p}$-value $\leq 5 \times 10^{-8}$ ) heterogeneity in effects between racial groups was observed for $50 \%$ of the loci in children, and $12-18 \%$ of loci in adults.

\section{Discussion}

Dental caries is a complex disease that disproportionately affects certain groups, including African Americans.

This is one of few studies of the genetics of dental caries to specifically investigate African Americans. The purpose of this pilot study was to perform preliminary GWAS scans in African American children and adults and to contrast the evidence for genetic association between Africans Americans and Caucasians.

Though no significant associations were observed (which was expected given the small samples sizes), several suggestive loci showed strong evidence of genetic heterogeneity between African Americans and Caucasians. These findings suggest that the genetic architecture of dental caries differs across racial groups. Thus, gene-mapping efforts in African American and other minority racial groups are warranted, and may lead to the discovery of caries risk loci that would go undetected by studying Caucasians alone.

Several suggestive loci harboring genes with putative connections to caries were observed. Given the exploratory 
Table 1 Demographics of African-American and Caucasian cohorts included in the study

\begin{tabular}{|c|c|c|c|c|}
\hline \multirow{2}{*}{$\begin{array}{l}\text { Race } \\
\text { Cohort }\end{array}$} & \multicolumn{2}{|c|}{ African American } & \multicolumn{2}{|l|}{ Caucasian } \\
\hline & Adults & Children & Adults & Children \\
\hline $\bar{N}$ & 109 & 96 & 918 & 983 \\
\hline Age; mean (range) & $29.15(18-58)$ & $7.30(3-11)$ & $33.96(18-64)$ & $6.37(3-11)$ \\
\hline Male (\%) & $38(34.9 \%)$ & $48(50.0 \%)$ & $683(32.8 \%)$ & $616(50.7 \%)$ \\
\hline Female (\%) & $71(65.1 \%)$ & $48(50.0 \%)$ & $910(57.1 \%)$ & $599(49.3 \%)$ \\
\hline DMFT/dft; mean (range) & $7.17(0-28)$ & $2.21(0-12)$ & $10.39(0-28)$ & $1.96(0-17)$ \\
\hline DMFS/dfs; mean (range) & $18.2(0-106)$ & $4.90(0-35)$ & $23.00(0-122)$ & $3.85(0-53)$ \\
\hline PCs & 2 & 2 & 2 & 2 \\
\hline Genotyped SNPS & 529,015 & 529,837 & 526,525 & 510,212 \\
\hline Imputed SNPs & $4,907,119$ & $4,912,366$ & $4,915,678$ & $4,931,991$ \\
\hline
\end{tabular}

$P C$ s number of principal components adjust for in the GWAS

nature of this study, we describe suggestive hits to potentially help inform new hypotheses about caries genetics. We caution that these suggestive loci should be interpreted with much skepticism.

\section{GWASs of permanent dentition in African Americans}

Several themes emerged from annotation of suggestively associated genes, including saliva-, salivary gland-, and salivary proteome-related genes. A gene encoding a salivary protein involved in inflammatory processes (KLK1; rs4801855; $p$-value $3.24 \times 10^{-6}$ ) $[85,86]$, a transcription factor differentially expressed in the minor salivary glands between the sexes (LSG1; chr3:194035416; $p$ value $1.6 \times 10^{-7}$ ) [51], and a gene encoding a salivary protein (CTSB; rs2838538; p-value $4.34 \times 10^{-6}$ ) were identified.
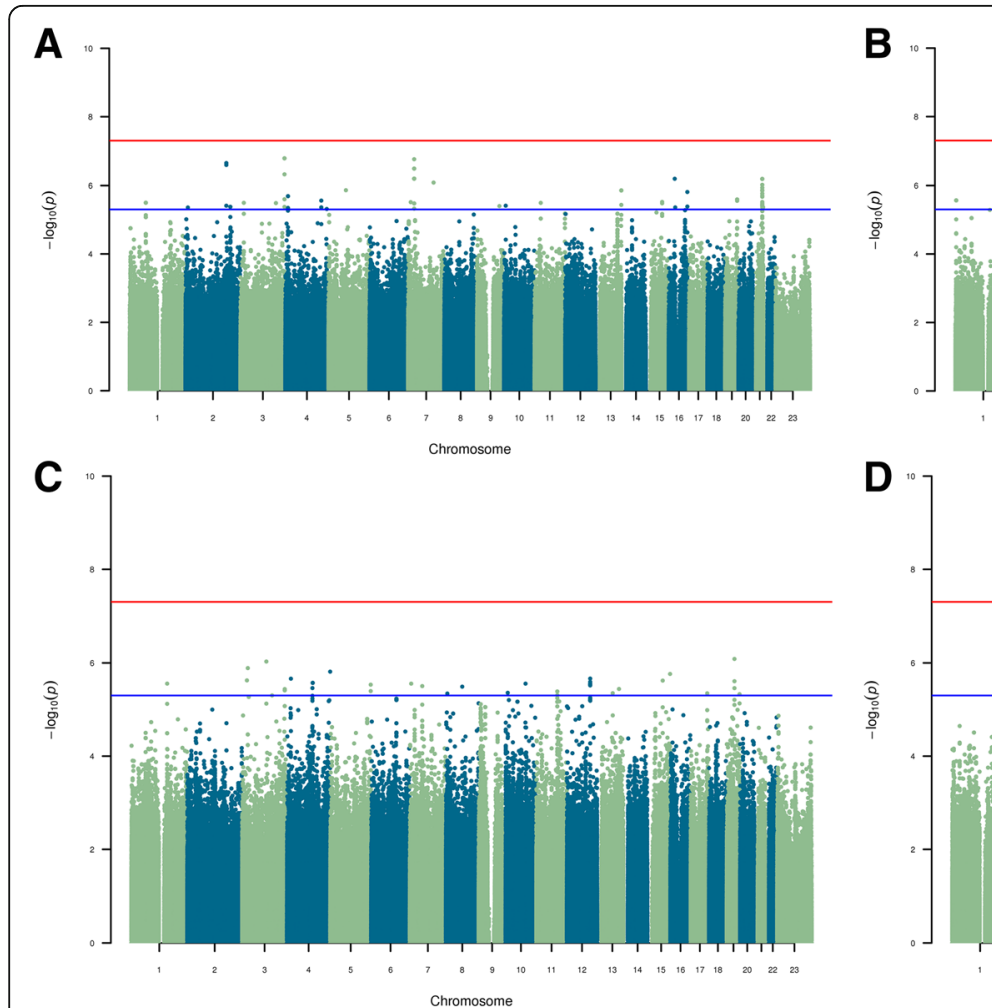

Fig. 1 Manhattan plots for the permuted results of a permanent DMFT b permanent DMFS c primary dft, and $\mathbf{d}$ primary dfs GWASs. P-values are $\log _{10}$-transformed. The red line signifies genome-wide significance $\left(p\right.$-value $\leq 5 \times 10^{-8}$ ), and the blue line signifies suggestive significance $\left(p\right.$-value $\left.<5 \times 10^{-6}\right)$ 


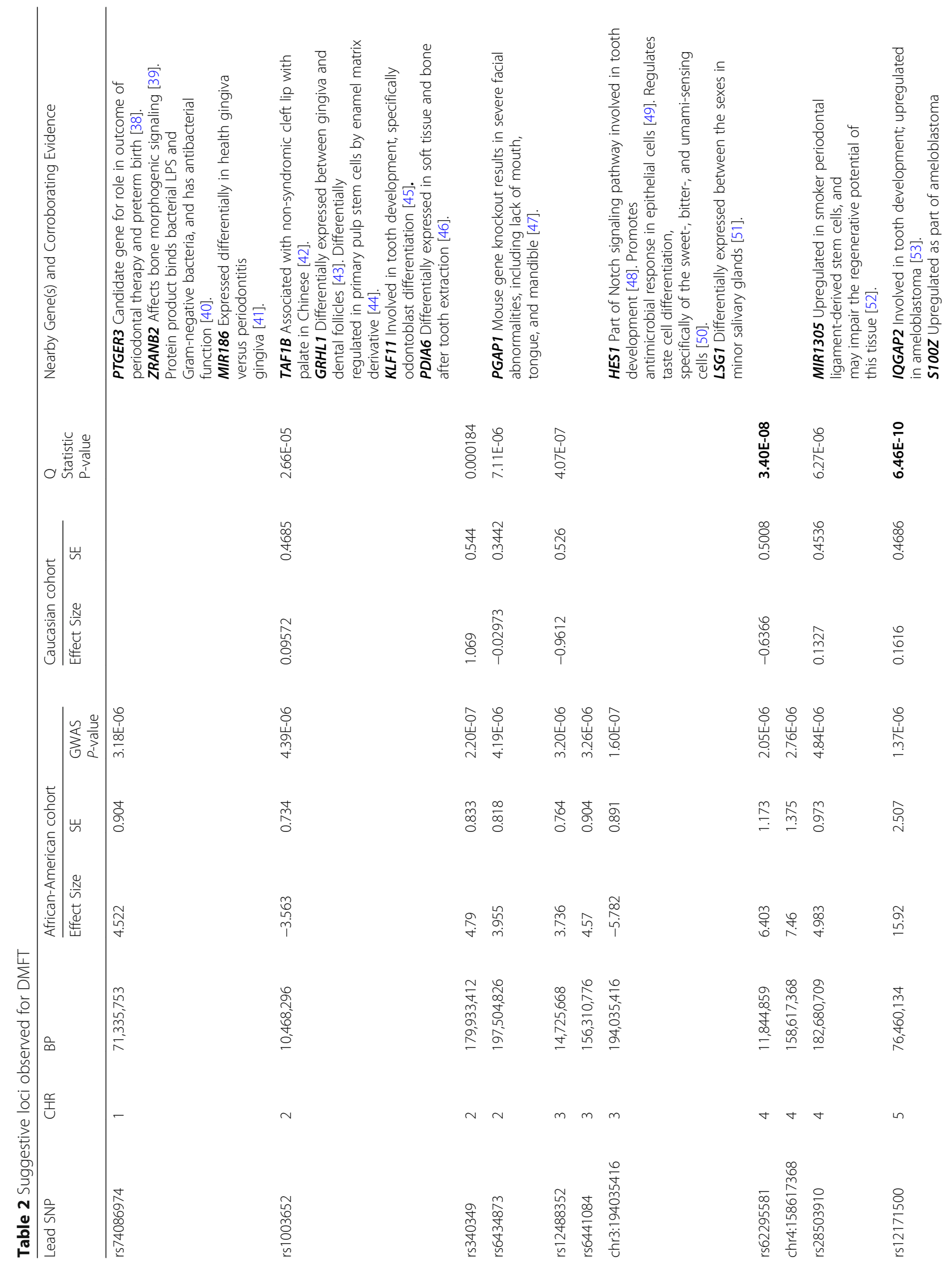




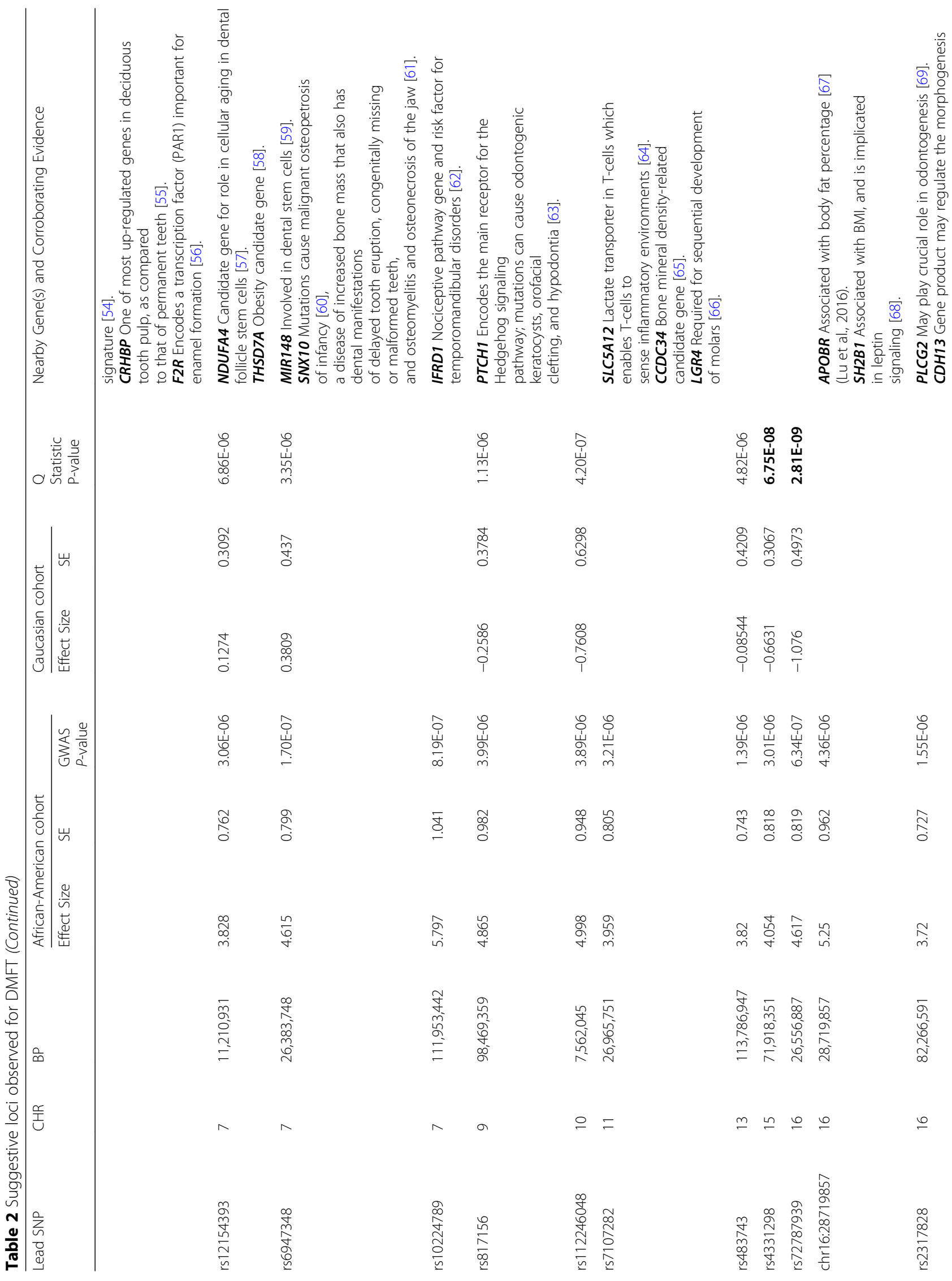


Orlova et al. BMC Oral Health $\quad$ (2019) 19:215

Page 7 of 21

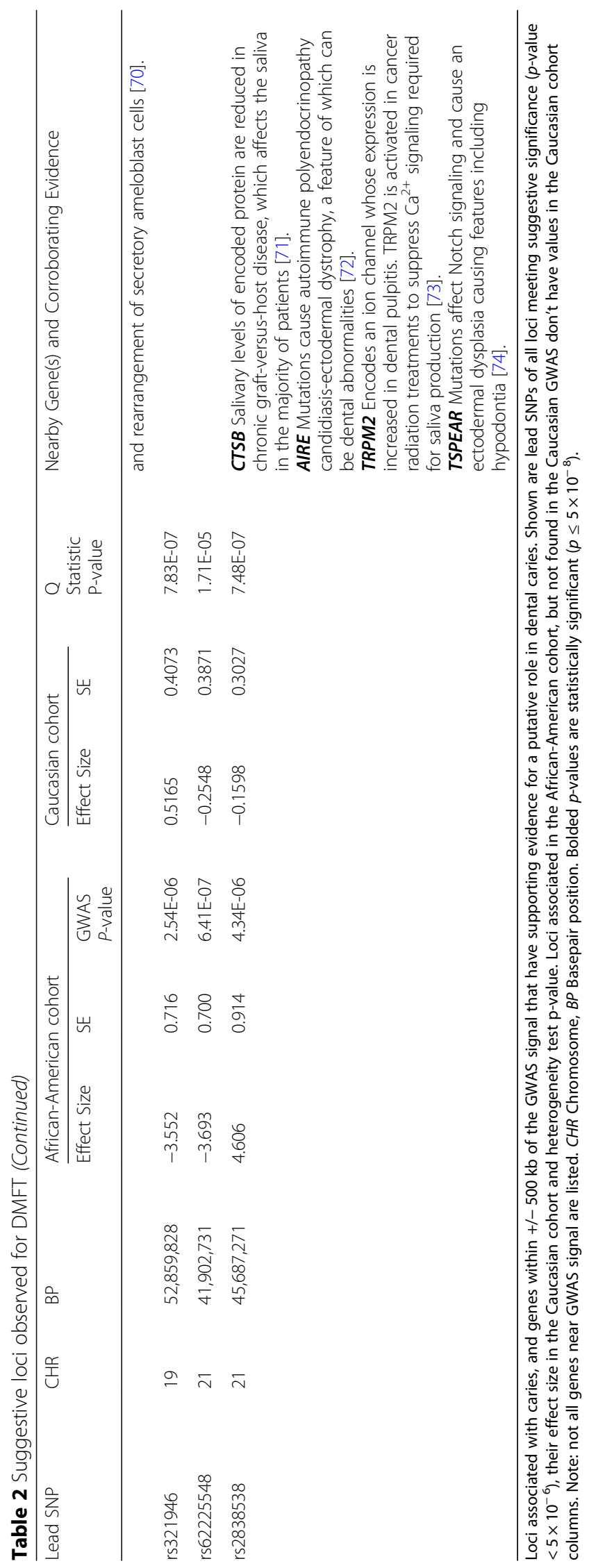


Orlova et al. BMC Oral Health $\quad$ (2019) 19:215

Page 8 of 21

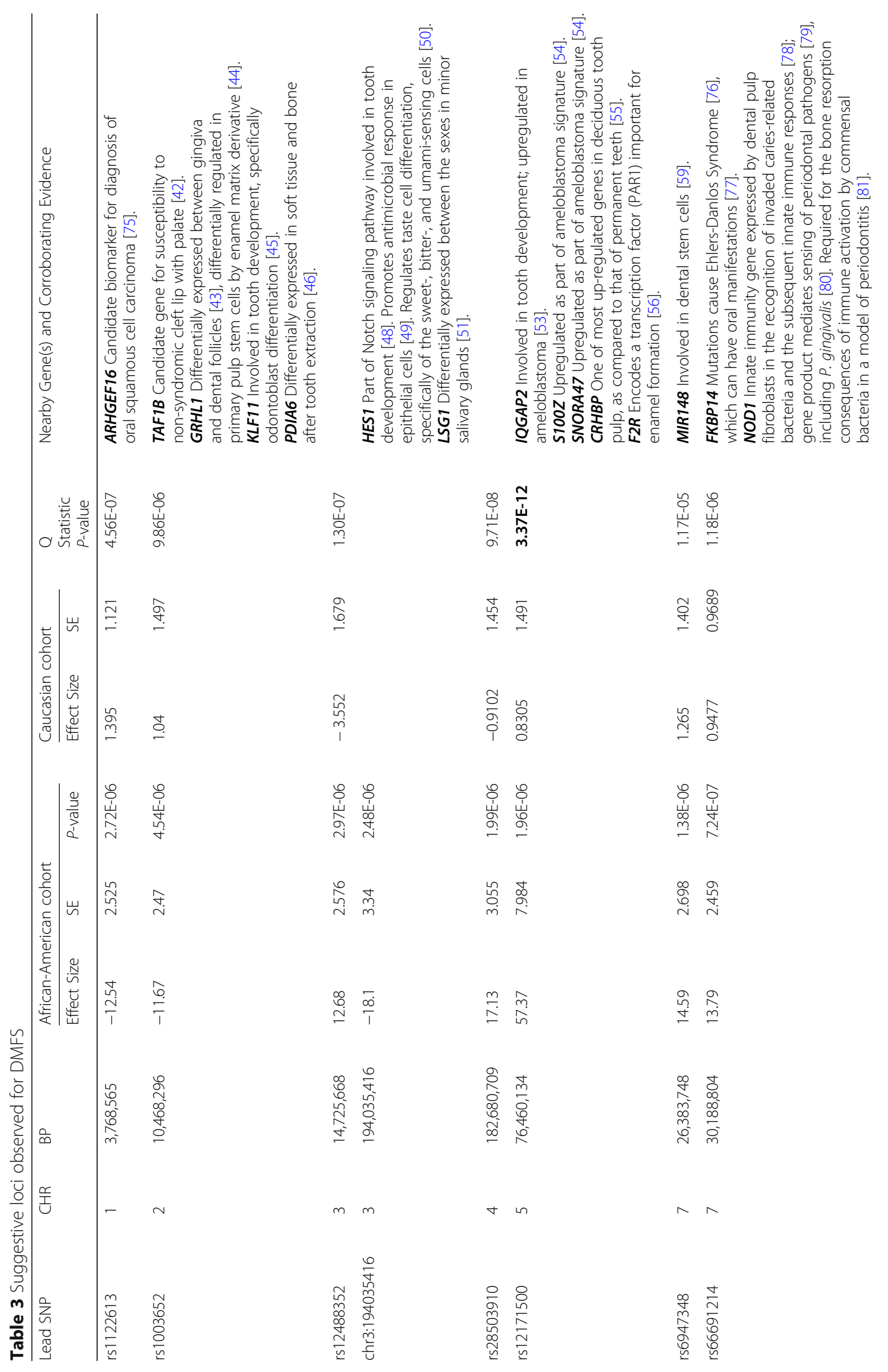




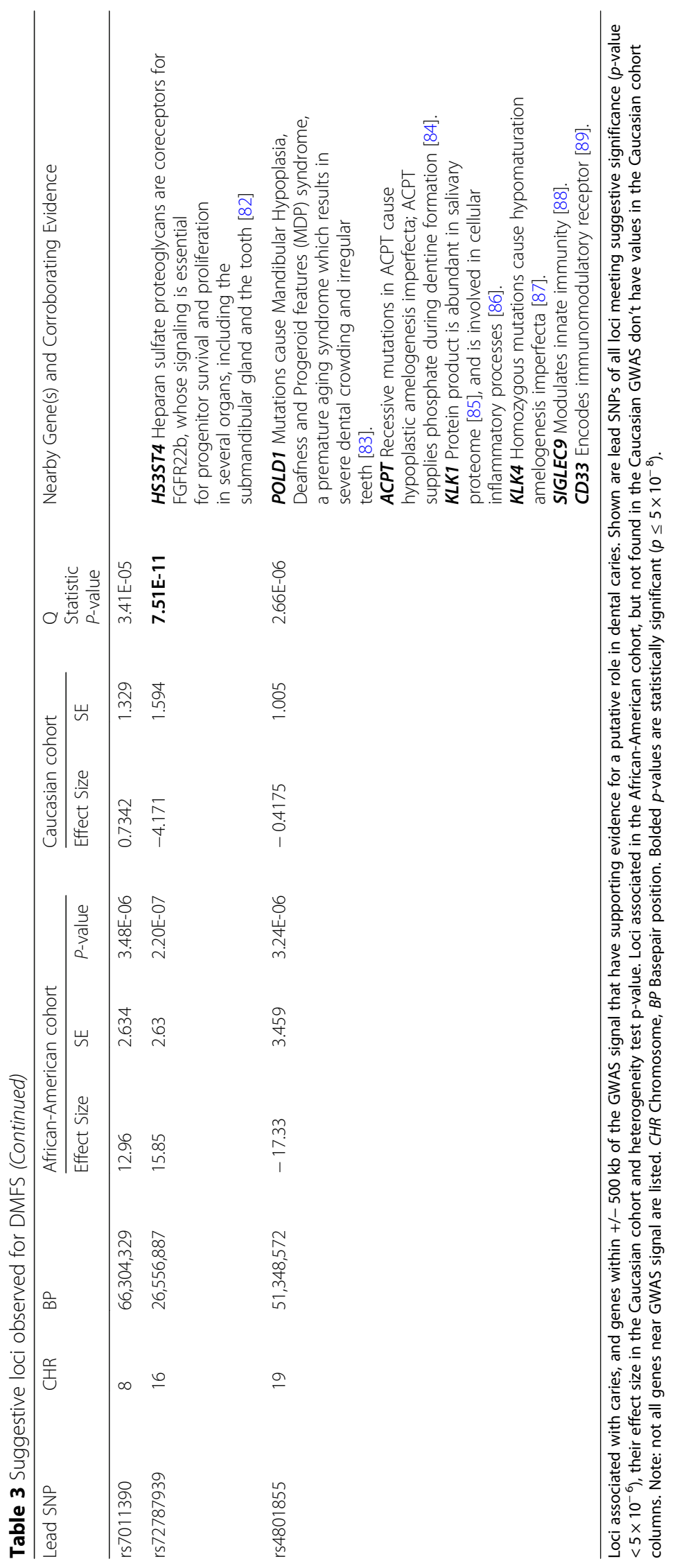




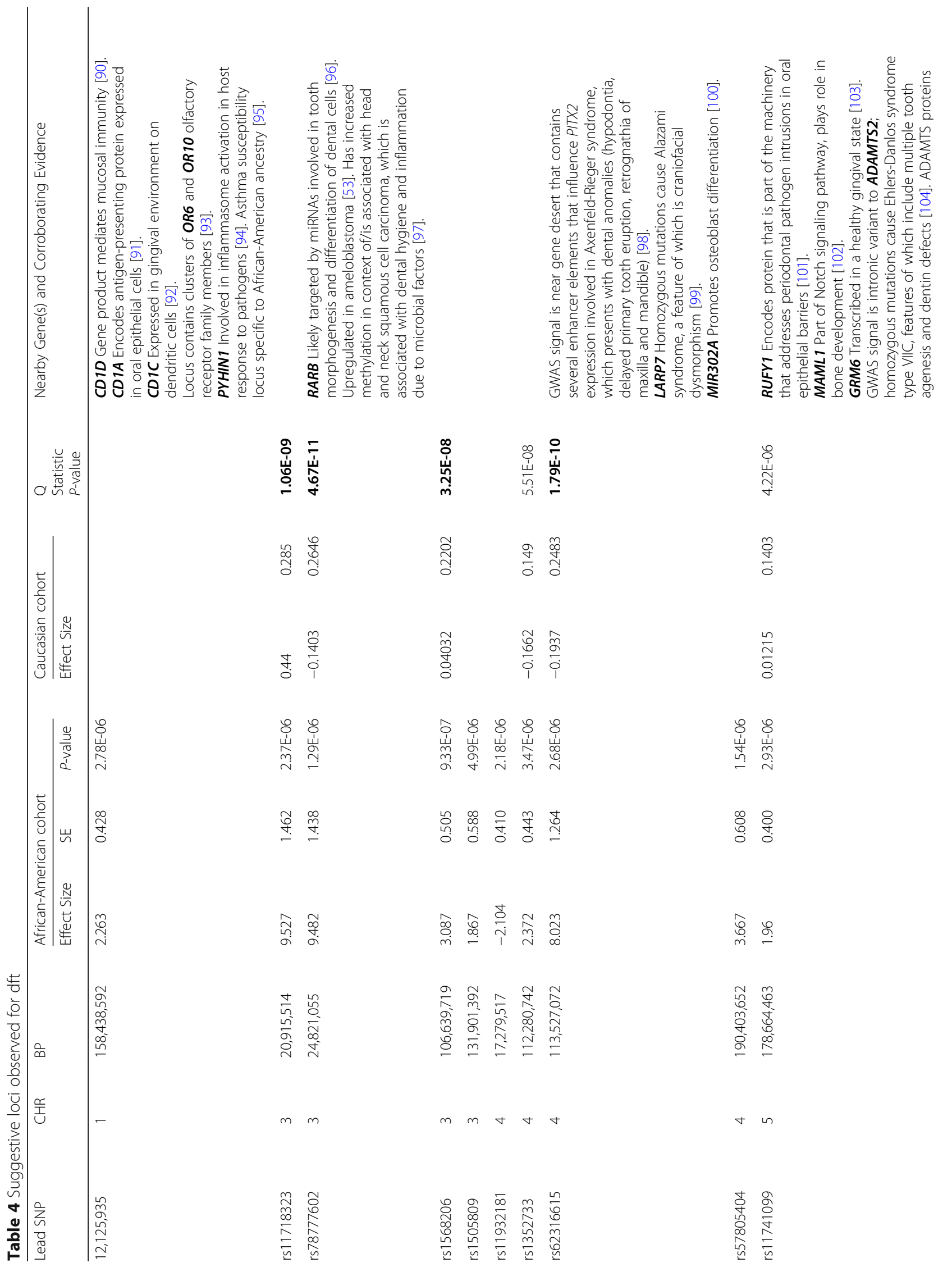




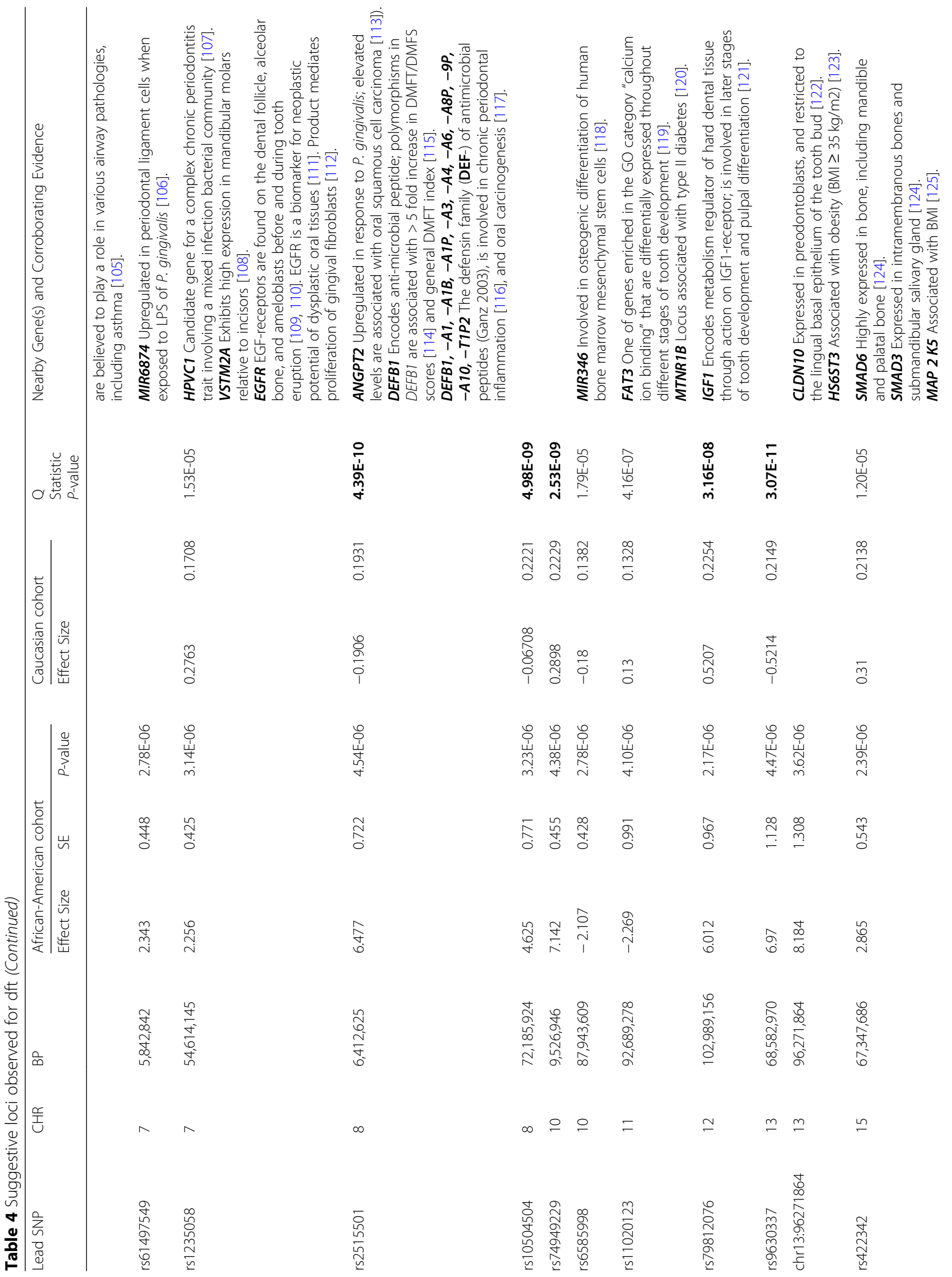


Orlova et al. BMC Oral Health $\quad$ (2019) 19:215

Page 12 of 21

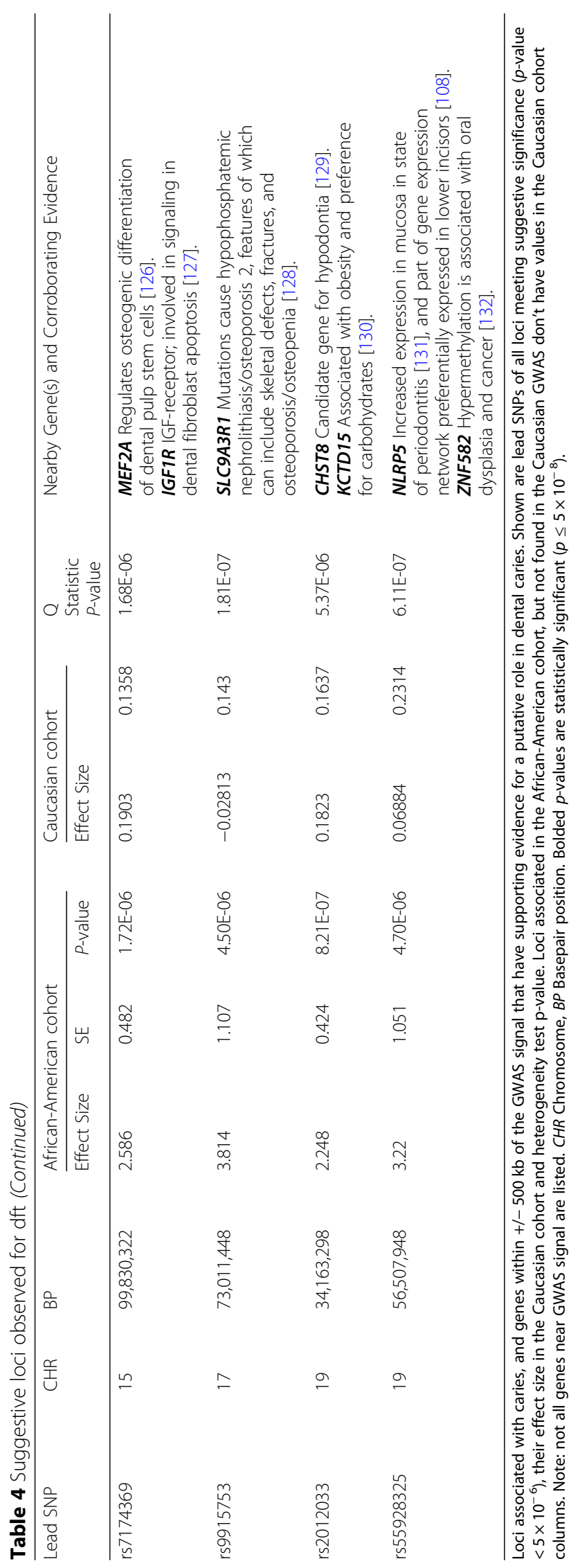




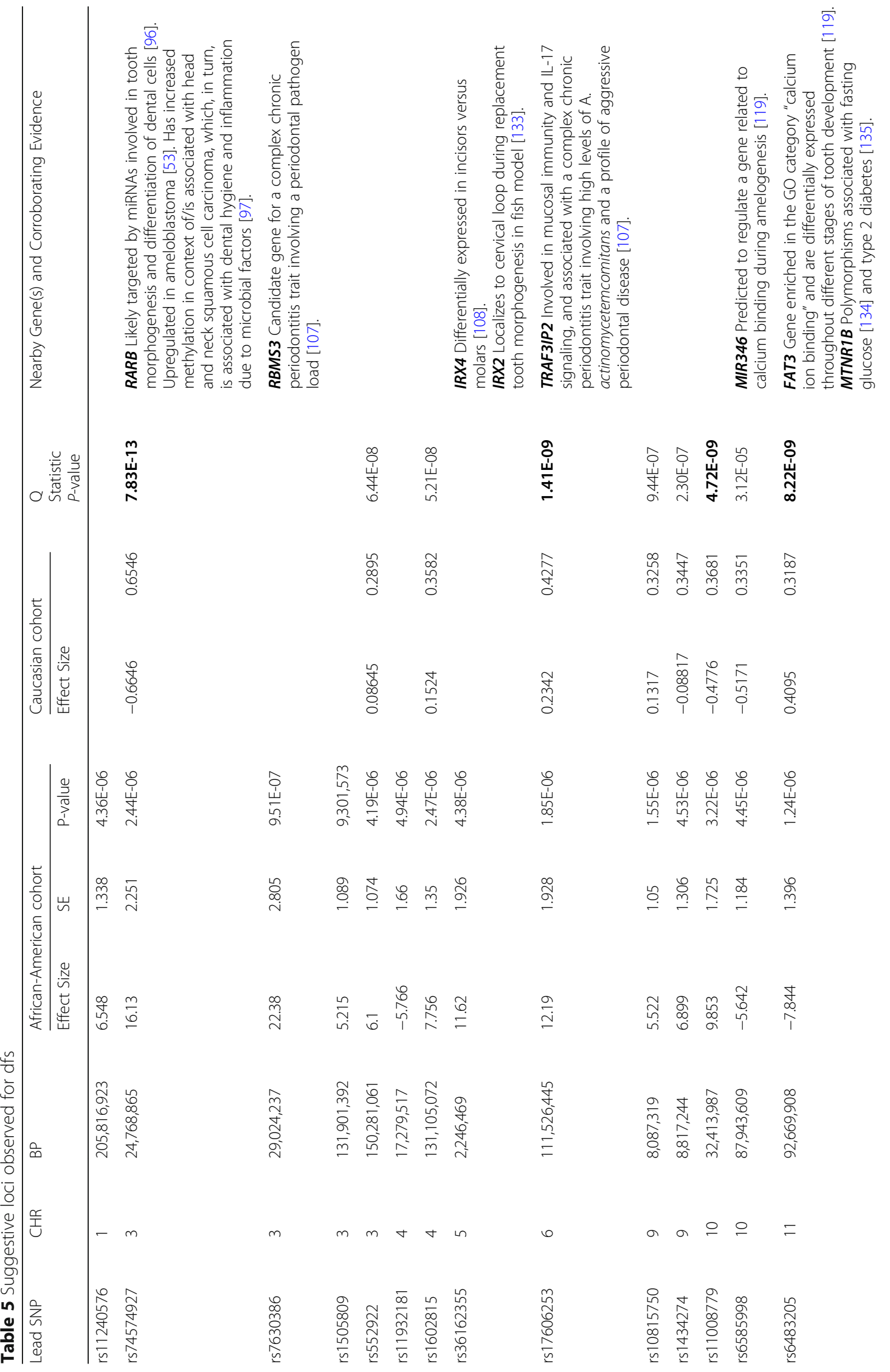




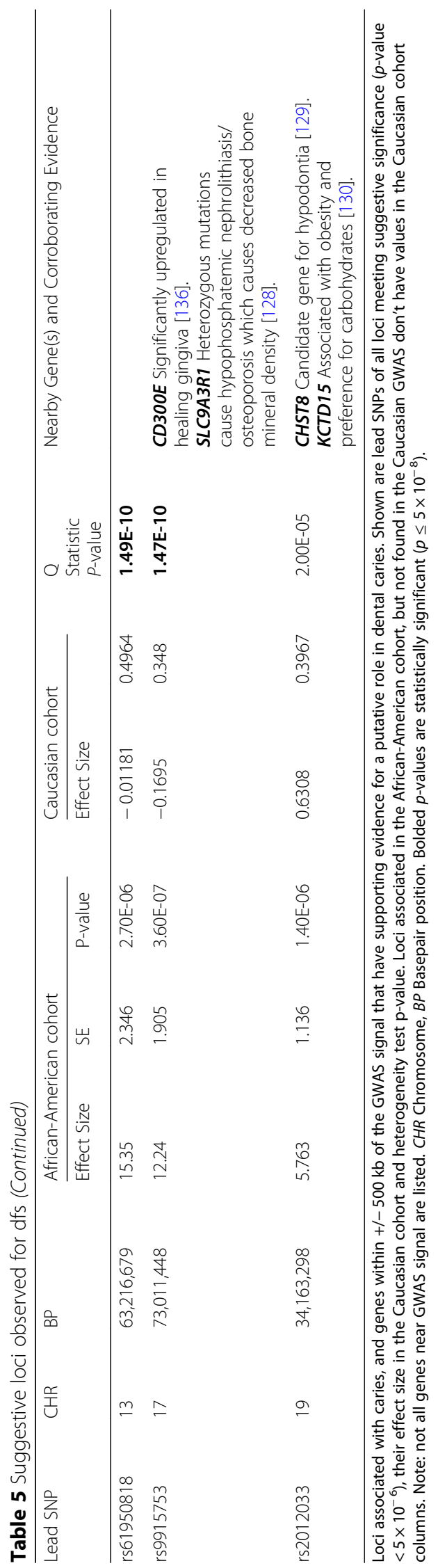


Table 6 Loci showing significant heterogeneity between African Americans and Caucasians caries GWASs

\begin{tabular}{|c|c|c|c|c|c|c|c|c|c|}
\hline Phenotype & SNP & $\mathrm{CHR}$ & $\mathrm{BP}$ & P-value (AA) & Effect Size (AA) & SE (AA) & Effect Size (C) & SE (C) & $\begin{array}{l}\text { Q Statistic } \\
\text { P-value }\end{array}$ \\
\hline \multirow[t]{4}{*}{ DMFT } & rs62295581 & 4 & $11,844,859$ & $2.05 \mathrm{E}-06$ & 6.403 & 1.173 & -0.6366 & 0.5008 & $3.40 \mathrm{E}-08$ \\
\hline & rs12171500 & 5 & $76,460,134$ & 1.37E-06 & 15.92 & 2.507 & 0.1616 & 0.4686 & $6.46 \mathrm{E}-10$ \\
\hline & rs4331298 & 15 & $71,918,351$ & $3.01 \mathrm{E}-06$ & 4.054 & 0.818 & -0.6631 & 0.3067 & $6.75 \mathrm{E}-08$ \\
\hline & rs72787939 & 16 & $26,556,887$ & $6.34 \mathrm{E}-07$ & 4.617 & 0.8189 & -1.076 & 0.4973 & 2.81E-09 \\
\hline \multirow[t]{2}{*}{ DMFS } & rs12171500 & 5 & $76,460,134$ & 1.96E-06 & 57.37 & 7.984 & 0.8305 & 1.491 & 3.37E-12 \\
\hline & rs72787939 & 16 & $26,556,887$ & $2.20 \mathrm{E}-07$ & 15.85 & 2.63 & -4.171 & 1.594 & $7.51 \mathrm{E}-11$ \\
\hline \multirow[t]{10}{*}{$\mathrm{dft}$} & rs11718323 & 3 & $20,915,514$ & $2.37 \mathrm{E}-06$ & 9.527 & 1.462 & 0.44 & 0.285 & $1.06 \mathrm{E}-09$ \\
\hline & rs78777602 & 3 & $24,821,055$ & $1.29 \mathrm{E}-06$ & 9.482 & 1.438 & -0.1403 & 0.2646 & $4.67 \mathrm{E}-11$ \\
\hline & rs1568206 & 3 & $1.07 E+08$ & $9.33 \mathrm{E}-07$ & 3.087 & 0.5053 & 0.04032 & 0.2202 & $3.25 \mathrm{E}-08$ \\
\hline & rs1112769 & 3 & $1.88 \mathrm{E}+08$ & 3.65E-06 & 5.947 & 0.9909 & -0.3341 & 0.2187 & $6.02 \mathrm{E}-10$ \\
\hline & rs62316615 & 4 & $1.14 \mathrm{E}+08$ & $2.68 \mathrm{E}-06$ & 8.023 & 1.264 & -0.1937 & 0.2483 & $1.79 \mathrm{E}-10$ \\
\hline & rs2515501 & 8 & $6,412,625$ & 4.54E-06 & 6.477 & 1.051 & -0.1906 & 0.1931 & 4.39E-10 \\
\hline & rs10504504 & 8 & $72,185,924$ & $3.23 \mathrm{E}-06$ & 4.625 & 0.771 & -0.06708 & 0.2221 & 4.98E-09 \\
\hline & rs74949229 & 10 & $9,526,946$ & 4.38E-06 & 7.142 & 1.128 & 0.2898 & 0.2229 & 2.53E-09 \\
\hline & rs79812076 & 12 & $1.03 E+08$ & 2.17E-06 & 6.012 & 0.9667 & 0.5207 & 0.2254 & $3.16 \mathrm{E}-08$ \\
\hline & rs9630337 & 13 & $68,582,970$ & 4.47E-06 & 6.97 & 1.107 & -0.5214 & 0.2149 & 3.07E-11 \\
\hline \multirow[t]{6}{*}{ dfs } & rs74574927 & 3 & $24,768,865$ & 2.44E-06 & 16.13 & 2.251 & -0.6646 & 0.6546 & $7.83 \mathrm{E}-13$ \\
\hline & rs17606253 & 6 & $1.12 \mathrm{E}+08$ & $1.85 \mathrm{E}-06$ & 12.19 & 1.928 & 0.2342 & 0.4277 & $1.41 \mathrm{E}-09$ \\
\hline & rs11008779 & 10 & $32,413,987$ & $3.22 \mathrm{E}-06$ & 9.853 & 1.725 & -0.4776 & 0.3681 & 4.72E-09 \\
\hline & rs61950818 & 13 & $63,216,679$ & 2.70E-06 & 15.35 & 2.346 & -0.01181 & 0.4964 & 1.49E-10 \\
\hline & rs9915753 & 17 & $73,011,448$ & 3.60E-07 & 12.24 & 1.905 & -0.1695 & 0.348 & $1.47 \mathrm{E}-10$ \\
\hline & rs74574927 & 3 & $24,768,865$ & $2.44 \mathrm{E}-06$ & 16.13 & 2.251 & -0.6646 & 0.6546 & $7.83 \mathrm{E}-13$ \\
\hline
\end{tabular}

CHR Chromosome, BP Basepair, AA African American, C Caucasian. Significance threshold is $p$-value $\leq 5 \times 10^{8}$.

Several genes related to the immune response and periodontal disease were identified. HES1 (chr3:194035416) encodes a transcription factor with roles in antimicrobial response within epithelial cells [49]. NOD1 (rs66691214; $p$ value $7.24 \times 10^{-7}$ ) encodes a dental pulp protein with roles in sensing caries-related [78] and periodontal pathogens $[79,80]$, and the subsequent immune response $[78,81]$. Protein products of several genes are involved in innate immunity [64, 88] (SIGLEC9, CD33; rs4801855; $p$-value $3.24 \times 10^{-6}$ and SLC5A12; rs7107282; $p$-value $3.21 \times 10^{-6}$ ). PTGER3 (rs74086974; p-value $3.18 \times 10^{-6}$ ) is a candidate gene for the outcome of periodontal disease therapy [38], and MIR186 (rs74086974) is differentially expressed between gingiva in health versus periodontitis [41]. rs28503910 ( $p$-value $\left.4.84 \times 10^{-6}\right)$ contained MIR1305, which is upregulated in response to smoking and may impair regeneration of periodontal tissues in that state [52]. TRPM2 (rs2838538; $p$-value $4.34 \times 10^{-6}$ ) encodes an ion channel upregulated in dental pulpitis [137], and is involved in saliva production [138].

Tooth and enamel development-related genes were present across several loci, including a gene associated at nominal significance, TUFT1 (rs11805632; $p$-value $5.15 \times$ $\left.10^{-6}\right)$, which had previously been found to be associated with dental caries in Caucasian children and adults, and which displays interaction with fluoride exposure [8]. Additional genes included HS3ST4 (rs72787939; $p$-value $2.20 \times$ $10^{-7}$ ), which encodes a co-receptor essential for submandibular gland and tooth progenitor function [82]. Genes with roles in dental stem cells (MIR148A; rs6947348; pvalue $1.38 \times 10^{-6}$ ) [59], and a locus with genes involved in tooth development (IQGAP2; rs12171500; p-value $1.96 \times$ $\left.10^{-6}\right)$ [53], enamel formation $(F 2 R)$ [56], deciduous tooth pulp (CRHBP) [55], and ameloblastoma (S100Z, SNORA47, IQGAP2) [53, 54], were found. Also, previously-mentioned HES1 (chr3:194035416) has a role in tooth development [48], and taste cell differentiation [50]. The rs 2317828 locus ( $p$-value $1.55 \times 10^{-6}$ ) contains genes that play a crucial role in odontogenesis (PLCG2) [56] and ameloblast development (CDH13) [70]. LGR4 (rs7107282; p-value $3.21 \times 10$ 6 ) is required for the sequential development of molars [66]. FOXF2 (rs2814820; $p$-value $3.90 \times 10^{-6}$ ) and TAF1B (rs1003652; p-value $4.54 \times 10^{-6}$ ) are near a cleft lip [139] and cleft lip and palate risk loci [88], respectively. FOXF2 also encodes a protein located near tooth germ cells during tooth development [140]. The rs1003652 (p-value 4.54× 
$10^{-6}$ ) locus includes several genes that are differentially expressed between various dental, bone, or gingival tissues (GRHL1, PDIA6) [44, 46], and one involved in odontoblast development (KLF11) [45].

Finally, several genes are involved in monogenic disorders with dental phenotypes, including SNX10 (malignant osteopetrosis of infancy, which can have features of delayed tooth eruption, missing or malformed teeth; rs6947348; $p$-value $1.7 \times 10^{-7}$ ) [61], a locus containing POLD1 (mandibular hypoplasia, deafness, progeroid features; rs4801855; $3.24 \times 10^{-6}$ ) [83], ACPT (hypoplastic amelogenesis imperfecta) [84], KLK4 (hypomaturation amelogenesis imperfecta) [87], a locus containing AIRE (autoimmune polyendocrinopathy candidiasis-ectodermal dystrophy, which can feature dental abnormalities; rs2838538; $p$-value $4.34 \times 10^{-6}$ ) [72], and TSPEAR (ectodermal dysplasia causing hypodontia) [74].

The locus chr16:28719857 ( $p$-value $4.36 \times 10^{-6}$ ) contains genes associated with body fat percentage $(A P O B R)$ [67] and BMI (SH2B1) [68], and rs12154393 (p-value $3.06 \times 10$ 6) contains $T H S D 7 A$, a candidate gene for obesity [58].

\section{GWASs of primary dentition in African Americans}

The locus near rs2012033 was associated in both primary caries GWASs (dft $p$-value $8.21 \times 10^{-7}$; dfs p-value $1.40 \times$ $\left.10^{-6}\right)$ and harbored a candidate gene for hypodontia (CHST8) [129] and a gene associated with obesity and preference for carbohydrate (KCTD15) [130]. Other loci with connections to obesity and related disorders include chr13:96271864 ( $p$-value $3.62 \times 10^{-6}$ ) that harbors the obesity-associated gene HS6ST3 [123], rs422342 (2.39 × $10^{-6}$ ), which includes MAP $2 \mathrm{~K} 5$, also associated with BMI [125], and rs6483205 (p-value $1.24 \times 10^{-6}$ ) which contains MTNR1B, polymorphisms in which are associated with fasting glucose [134] and type 2 diabetes [135].

The locus rs2515501 ( $\mathrm{p}$-value $4.54 \times 10^{-6}$ ) harbored several members of the alpha and beta defensin family of antimicrobial peptides [141], which are involved in chronic periodontal inflammation [116] and oral carcinogenesis [117]. Of note, this locus contains $D E F B 1$, polymorphisms in which are associated with a $>5$ fold increase in DMFT and DMFS scores [114], and general DMFT index [115]. An additional gene at this locus, ANGPT2, is also associated with oral cancer, and upregulated in response to $P$. gingivalis, a periodontal pathogen [113].

Three separate associated loci harbored genes associated with complex periodontal traits, proxies for different subgroups of periodontal disease, a condition closely associated with dental caries [142]. rs1235058 ( $p$-value 3.14 $\times$ 10-6) harbored $H P V C 1$, a candidate gene for a trait involving a mixed infection bacterial community [107]. rs7630386 (p-value $9.51 \times 10^{-7}$ ) harbored RBMS3, a candidate gene for a trait involving a high periodontal pathogen load [107]. Thirdly, rs17606253 ( $p$-value $\left.1.85 \times 10^{-6}\right)$ harbored TRAF3IP2, a protein implicated in mucosal immunity and IL-17 signaling, and associated with a trait involving high levels of $A$. actinomycetemcomitans and a profile of aggressive periodontal disease [107].

Two loci were found to be related to asthma, a disease associated with a doubled risk of caries [143]. rs12125935 ( $p$-value $\left.2.78 \times 10^{-6}\right)$ harbors PYHIN1, which encodes a protein involved in inflammasome activation in response to pathogens [94], and represents an asthma susceptibility locus specific to African-American ancestry [95]. rs11741099 ( $p$-value $2.93 \times 10^{-6}$ ) is intronic to ADAMTS2; the ADAMTS protein family is proposed to play a role in asthma [105]. Additionally, homozygous mutations in ADAMTS2 cause Ehlers-Danlos syndrome (VIIC), features of which can include multiple tooth agenesis and dentin defects [104].

rs7174369 ( $p$-value $1.72 \times 10^{-6}$ ) harbored IGF1R, involved in dental fibroblast apoptosis [127]. Interestingly, in addition to its receptor, the regulator of hard dental tissue encoded by IGF1 was also associated at a separate locus (rs79812076; p-value $2.17 \times 10^{-6}$ ).

\section{Comparison between association results across dentition type and across races}

Aside from TUFT1 and DEFB1, the loci reported here have not been associated with dental caries in previous studies, which have largely comprised Caucasian individuals. This is in line with previous research showing differences in frequencies of risk alleles for complex disease across races, but may also be because the study was underpowered to detect associated loci in African Americans. In addition, no overlap was found in associated loci between this study and a multi-ethnic pilot GWAS of early childhood caries [144]. There was no overlap in loci associated with primary and permanent caries indices, but this might be expected given that the genetic determinants of caries are thought to largely differ between the dentitions [6]. However we cannot rule out similarities in genetic determinants across dentitions because this pilot study was not designed to have sufficient power for this purpose.

Loci displaying significant heterogeneity between African Americans and Caucasians (Table 6) in permanent dentition were largely ones in gene deserts with unknown function. One locus (rs12171500; DMFT Q statistic [Q] $p$-value $6.46 \mathrm{x}^{-10}$; DMFS Q $p$-value $3.37 \mathrm{x}^{-12}$ ) contained genes involved in enamel and tooth development.

Among loci displaying significant heterogeneity in primary dentition, there were several that harbored genes related to periodontitis. Such loci represented genes related to periodontal inflammation ( $r$ 2515501; Q p-value $4.39 \mathrm{x}^{-10}$ ), gingival healing (rs9915753; dft Q p-value 1.81x ${ }^{-07}$, dfs Q pvalue $1.47 \mathrm{x}^{-10}$ ), and aggressive periodontal disease and high levels of oral A. actinomycetemcomitans (rs17606253; Q p- 
value $\left.1.41 \mathrm{x}^{-9}\right)$. Notably, African American pre-teens are approximately 16 times as likely as Caucasian ones to have localized aggressive periodontitis and detection of $A$. actinomycetemcomitans is associated with early surrogates for periodontal inflammation in African American preadolescents [145].

Several broad categories of genes associated with caries in African Americans emerged, including those involved in tooth/enamel development, those causing single-gene disorders with craniofacial or dental malformations, those involved in immune response or periodontitis, those related to salivary glands and proteins, and those associated with obesity. These results support the known multifactorial nature of dental caries [21]. Further studies will be necessary to confirm the loci nominated in this pilot study. Nevertheless, these GWASs provide valuable insight into the differences in the genetic architecture of caries across populations, and suggest new candidate genes worth following-up in hypothesis-driven studies.

\section{Study limitations}

This study has limitations, including the genotyping platform, which was not optimized for genomic coverage of the African American population [146, 147]. Thus, studies in larger African American cohorts and with denser chips are needed to identify risk loci that may not have been well represented in this study. The ascertainment of caries was limited by the lack of X-ray examination to confirm white spots and approximal tooth surface caries, which would have underestimated the true extent of caries counts. Imprecision in the caries assessment would lower the power to detect association, but would not result in false positive associations. Therefore, the associations observed in this study would likely not be influenced by this limitation, but other true associations may have gone undetected. The pediatric cohort analyses were somewhat limited in that the primary caries indices (dfs/dft) were tested for genetic association in a sample that included some children with mixed dentition. Limiting the scope of the pediatric analyses to solely primary dentition caries indices allows for simplified interpretation of the association results because genetic determinants of primary and permanent tooth caries have been found to differ [6]. However, assessing $\mathrm{dfs} / \mathrm{dft}$ scores in the mixed dentition provides an incomplete picture of the caries experience in the primary dentition, given the exfoliation of some teeth. This is another important source of measurement error, which would bias our analysis toward the null hypothesis of no association.

\section{Conclusions}

In summary, these results suggest that there may be genetic differences in caries susceptibility, and potentially differing genetic etiologies or differentially distributed genetic risk factors, across racial groups. Indeed, addressing the oral health disparity gap is a national priority according to both the US Surgeon General's Oral Health in America report [12] and the Healthy People 2020 public health goal framework [148]. This oral health disparity has parallels in the research sphere - relatively little work, to date, has been done on the genetics of caries in African Americans. Furthermore, African Americans represent a segment of the population traditionally underrepresented in biomedical research (UBR) and the importance of including such groups in research is recognized as foundational to the future of precision medicine by the National Institutes of Health initiative, All of Us [149]. Larger gene-mapping studies are thus needed in this population to help alleviate its disproportionate burden of the disease.

\section{Abbreviations}

dfs: Number of decayed or filled primary tooth surfaces; dft: Number of decayed or filled primary teeth; DMFS: Number of decayed, missing, or filled permanent tooth surfaces; DMFT: Number of decayed, missing, or filled permanent teeth; GWAS: Genome-wide association study; MAF: Minor allele frequency; SNP: Single nucleotide polymorphism

Acknowledgements

The authors are grateful for the participation of the research subjects, and the past and present research staff who have made this work possible.

\section{Authors' contributions}

$E O, J C, M L, E F, D M, R C, R W, M M$, and JS contributed to the design of the study. EO, JC and ML contributed to the analysis of the data. EO, JC, ML, EF, DM, RC, RW, MM, and JS interpreted the data. EO drafted the work, and JC, $M L, E F, D M, R C, R W, M M$, and JS critically revised it. All authors provided consent for publication and agree to be held accountable for all aspects of the work. All authors read and approved the final manuscript.

\section{Funding}

This work was funded through NIH grants U01-DE018903, R01-DE014899, and R03-DE024264. Genotyping was performed as part of the GENEVA consortium by the Center for Inherited Disease Research (www.cidr.jhmi.edu) through NIH contract HHSN268200782096C. Genotype data cleaning, quality assurance, and imputation were conducted in conjunction with the GENEVA coordinating center, funded through U01-HG004446. The funding bodies were not otherwise involved in the design of the study, nor the collection, analysis or interpretation of data and writing of the manuscript.

\section{Availability of data and materials}

The datasets analysed during the current study are available in the dbGaP repository (Study Accession: phs000095.v3.p1). Senior and NIH Investigators are eligible to apply for access.

Ethics approval and consent to participate

Study approval was granted by the University of Pittsburgh Institutional Review Board (coordinating center approval \# 0207073, Pennsylvania site approval \# 0506048) and the West Virginia University Institutional Review Board (approval \# 15620B). All participants provided consent or assent with written parental informed consent in accordance with IRB policies of the participating universities.

Consent for publication

Not applicable.

\section{Competing interests}

The authors declare that they have no competing interests with respect to the authorship and/or publication of this article. 


\section{Author details}

${ }^{1}$ Department of Human Genetics, Pittsburgh, USA. ${ }^{2}$ Department of Biostatistics, Graduate School of Public Health, Pittsburgh, USA. ${ }^{3}$ Center for Craniofacial and Dental Genetics, Dept. of Oral Biology, School of Dental Medicine, University of Pittsburgh, Pittsburgh, PA, USA. ${ }^{4}$ Departments of Psychology, \& Dental Practice and Rural Health, West Virginia University, Morgantown, USA. ${ }^{5}$ Department of Periodontics, School of Dentistry, West Virginia University, Morgantown, WV, USA. ${ }^{6}$ Department of Dental Public Health and Information Management, Pittsburgh, USA. ${ }^{7}$ Clinical and Translational Sciences Institute, University of Pittsburgh, Pittsburgh, PA, USA. ${ }^{8}$ Department of Psychiatry, School of Medicine, University of Pittsburgh, Pittsburgh, PA, USA.

Received: 22 February 2018 Accepted: 30 August 2019 Published online: 18 September 2019

\section{References}

1. Bretz WA, Corby PM, Schork NJ, Robinson MT, Coelho M, Costa S, et al. Longitudinal analysis of heritability for dental caries traits. J Dent ResNIH Public Access. 2005:84:1047-51.

2. Hunter PB. Risk factors in dental caries. Int Dent J. 1988;38:211-7.

3. Anderson M. Risk assessment and epidemiology of dental caries: review of the literature. Pediatr Dent. 2002;24:377-85.

4. Oscarson N, Espelid I, Jönsson B. Is caries equally distributed in adults? A population-based cross-sectional study in Norway - the TOHNN-study. Acta Odontol Scand. 2017;75:557-63.

5. Shaffer JR, Wang X, Desensi RS, Wendell S, Weyant RJ, Cuenco KT, et al. Genetic susceptibility to dental caries on pit and fissure and smooth surfaces. Caries ResKarger Publishers. 2012;46:38-46.

6. Wang X, Shaffer JR, Weyant RJ, Cuenco KT, DeSensi RS, Crout R, et al. Genes and their effects on dental caries may differ between primary and permanent dentitions. Caries ResKarger Publishers. 2010;44:277-84.

7. Shaffer JR, Wang X, McNeil DW, Weyant RJ, Crout R, Marazita ML. Genetic susceptibility to dental caries differs between the sexes: a family-based study. Caries Res. 2015:49:133-40.

8. Shaffer JR, Carlson JC, Stanley BOC, Feingold E, Cooper M, Vanyukov MM, et al. Effects of enamel matrix genes on dental caries are moderated by fluoride exposures. Hum GenetNIH Public Access. 2015;134:159-67.

9. Colak H, Dülgergil CT, Dalli M, Hamidi MM. Early childhood caries update: a review of causes, diagnoses, and treatments. J Nat Sci Biol MedMedknow Publications. 2013:4:29-38.

10. Dye BA, Thornton-Evans G, Li X, lafolla TJ. Dental caries and tooth loss in adults in the United States, 2011-2012 key findings. Hyattsville: NCHS Data Brief; 2015.

11. Dye BA, Thornton-Evans G, Li X, lafolla TJ. Dental caries and sealant prevalence in children and adolescents in the United States, 2011-2012. NCHS Data Brief. 2015;(191):1-8.

12. U.S. Department of Health and Human Services. Oral Health in America: A Report of the Surgeon General. J Calif Dent Assoc. 2000:308.

13. Pourat N, Finocchio L. Racial and ethnic disparities in dental care for publicly insured children. Health Aff. 2010;29:1356-63.

14. Schrimshaw EW, Siegel K, Wolfson NH, Mitchell DA, Kunzel C. Insurancerelated barriers to accessing dental care among African American adults with oral health symptoms in Harlem, new York City. Am J Public HealthAmerican Public Health Association. 2011:101:1420-8.

15. Finlayson TL, Siefert K, Ismail Al, Delva J, Sohn W. Reliability and validity of brief measures of oral health-related knowledge, fatalism, and self-efficacy in mothers of African American children. Pediatr Dent. 2005;27:422-8.

16. Li Y, Dasanayake AP, Caufield PW, Elliott RR, Butts JT. Characterization of maternal mutans streptococci transmission in an African American population. Dent Clin N Am. 2003:47:87-101.

17. Velliyagounder K, Kaplan JB, Furgang D, Legarda D, Diamond G, Parkin RE, et al. One of two human lactoferrin variants exhibits increased antibacterial and transcriptional activation activities and is associated with localized juvenile periodontitis. Infect ImmunAmerican Society for Microbiology (ASM). 2003;71:6141-7.

18. Acton RT, Dasanayake AP, Harrison RA, Li Y, Roseman JM, Go RC, et al. Associations of MHC genes with levels of caries-inducing organisms and caries severity in African-American women. Hum Immunol. 1999:60:984-9.

19. Marques PI, Fonseca F, Sousa T, Santos P, Camilo V, Ferreira Z, et al. Adaptive evolution favoring KLK4 downregulation in east Asians. Mol Biol Evol. 2016;33:93-108
20. Conry JP, Messer LB, Boraas JC, Aeppli DP, Bouchard TJ. Dental caries and treatment characteristics in human twins reared apart. Arch Oral Biol. 1993;38:937-43.

21. Shaffer JR, Marazita ML. In: Sonis ST, editor. Genomics, personalized medicine and Oral disease. Boston: Springer; 2015. p. 117-44.

22. Chen R, Corona E, Sikora M, Dudley JT, Morgan AA, Moreno-Estrada A, et al. Type 2 diabetes risk alleles demonstrate extreme directional differentiation among human populations, compared to other diseases. PLoS Genet. 2012;8:e1002621.

23. Taylor MR, Sun AY, Davis G, Fiuzat M, Liggett SB, Bristow MR. Race, common genetic variation, and therapeutic response disparities in heart failure. JACC Heart Fail NIH Public Access. 2014;2:561-72.

24. Tal R, Seifer DB. Potential mechanisms for racial and ethnic differences in antimüllerian hormone and ovarian reserve. Int J EndocrinolHindawi Limited. 2013:2013:818912.

25. Ioannidis JPA, Ntzani EE, Trikalinos TA. "Racial" differences in genetic effects for complex diseases. Nat GenetNature Publishing Group. 2004;36:1312-8.

26. Wojcik GL, Graff M, Nishimura KK, et al. Genetic analyses of diverse populations improves discovery for complex traits. Nature. 2019;570(7762): 514-8. https://doi.org/10.1038/s41586-019-1310-4.

27. Polk DE, Weyant RJ, Crout RJ, McNeil DW, Tarter RE, Thomas JG, et al. Study protocol of the Center for Oral Health Research in Appalachia (COHRA) etiology study. BMC Oral HealthBioMed Central. 2008;8:18.

28. Shaffer JR, Wang X, Feingold E, Lee M, Begum F, Weeks DE, et al. Genomewide association scan for childhood caries implicates novel genes. J Dent Res. 2011;90:1457-62.

29. Delaneau O, Marchini J, Zagury J-F. A linear complexity phasing method for thousands of genomes. Nat Methods. 2011;9:179-81.

30. Howie BN, Donnelly P, Marchini J, Hardy J, Abecasis G. A flexible and accurate genotype imputation method for the next generation of genomewide association studies. PLoS GenetRoberts \& Company Publishers. 2009;5: e1000529.

31. Wang X, Shaffer JR, Zeng Z, Begum F, Vieira AR, Noel J, et al. Genome-wide association scan of dental caries in the permanent dentition. BMC Oral Health. 2012;12:57

32. World Health Organization Oral Health Program. A guide to oral health epidemiological investigations. Geneva: The Organization; 1979

33. Drury TF, Horowitz AM, Ismail Al, Maertens MP, Rozier RG, Selwitz RH. Diagnosing and reporting early childhood caries for research purposes. A report of a workshop sponsored by the National Institute of Dental and Craniofacial Research, the Health Resources and Services Administration, and the health care financing Administ. J Public Health Dent. 1999:59:192-7.

34. Dye BA, Tan S, Smith V, Lewis BG, Barker LK, Thornton-Evans G, et al. Trends in oral health status: United States, 1988-1994 and 1999-2004. Vital Health Stat. 2007:11:1-92

35. Purcell S, Neale B, Todd-Brown K, Thomas L, Ferreira MAR, Bender D, et al. PLINK: a tool set for whole-genome association and population-based linkage analyses. Am J Hum Genet Elsevier. 2007;81:559-75.

36. R Development Core Team. R: a language and environment for statistical computing. Vienna: R Foundation for Statistical Computing; 2008. p. 2008.

37. McLean CY, Bristor D, Hiller M, Clarke SL, Schaar BT, Lowe CB, et al. GREAT improves functional interpretation of cis-regulatory regions. Nat Biotechnol. 2010; 28:495-501.

38. Jeffcoat MK, Jeffcoat RL, Tanna N, Parry SH. Association of a Common Genetic Factor, PTGER3, with outcome of periodontal therapy and preterm birth. J Periodontol. 2014;85:446-54.

39. Ohte S, Kokabu S, lemura S, Sasanuma H, Yoneyama K, Shin M, et al. Identification and functional analysis of Zranb2 as a novel Smad-binding protein that suppresses BMP signaling. J Cell BiochemWiley Subscription Services, Inc., A Wiley Company. 2012;113:808-14.

40. Wang $X$, Du $X$, Li H, Zhang S. ZRANB2-a novel maternal LPS-binding protein identification of the zinc finger protein ZRANB2 as a novel maternal LPSbinding protein that protects embryos of zebrafish against gram-negative bacterial infections. J Biol Chem. 2016:291:4019-34.

41. Hwa Lee $Y$, Sam HN, Yeon Jeong S, Hee Jeong S, Ryoun Park H, Chung J. Comparison of inflammatory microRNA expression in healthy and periodontitis tissues. BIOCELL. 2011;35:43-9.

42. Yu Y, Zuo X, He M, Gao J, Fu Y, Qin C, et al. Genome-wide analyses of nonsyndromic cleft lip with palate identify 14 novel loci and genetic heterogeneity. Nat Commun. 2017:8:14364.

43. Kang C-M, Kim S-O, Jeon M, Choi H-J, Jung H-S, Lee J-H. Comparison of Stemness and gene expression between gingiva and dental follicles in children. Stem Cells Int. 2016;2016:1-11. 
44. Riksen E, Landin M, Reppe S, Nakamura Y, Lyngstadaas S, Reseland J. Enamel matrix derivative promote primary human pulp cell differentiation and mineralization. Int J Mol Sci. 2014;15:7731-49.

45. Chen Z, Li W, Wang H, Wan C, Luo D, Deng S, et al. Klf10 regulates odontoblast differentiation and mineralization via promoting expression of dentin matrix protein 1 and dentin sialophosphoprotein genes. Cell Tissue ResNIH Public Access. 2016;363:385-98.

46. Yang H-Y, Kwon J, Kook M-S, Kang SS, Kim SE, Sohn S, et al. Proteomic analysis of gingival tissue and alveolar bone during alveolar bone healing. Mol Cell ProteomicsAmerican Society for Biochemistry and Molecular Biology. 2013;12:2674-88.

47. Brommage R, Liu J, Hansen GM, Kirkpatrick LL, Potter DG, Sands AT, et al. High-throughput screening of mouse gene knockouts identifies established and novel skeletal phenotypes. Bone Res. 2014;2:14034.

48. Mustonen T, Tummers M, Mikami T, Itoh N, Zhang N, Gridley T, et al. Lunatic fringe, FGF, and BMP regulate the notch pathway during epithelial morphogenesis of teeth. Dev Biol. 2002;248:281-93.

49. Murano T, Okamoto R, Ito G, Nakata T, Hibiya S, Shimizu H, et al. Hes1 promotes the IL-22-mediated antimicrobial response by enhancing STAT3dependent transcription in human intestinal epithelial cells. Biochem Biophys Res Commun. 2014;443:840-6.

50. Ota MS, Kaneko Y, Kondo K, Ogishima S, Tanaka H, Eto K, et al. Combined in silico and in vivo analyses reveal role of Hes 1 in taste cell differentiation. PLoS Genet. 2009;5:e1000443.

51. Michael D, Soi S, Cabera-Perez J, Weller M, Alexander S, Alevizos I, et al. Microarray analysis of sexually dimorphic gene expression in human minor salivary glands. Oral DisNIH Public Access. 2011;17:653-61.

52. Ng TK, Huang L, Cao D, Yip YW-Y, Tsang WM, Yam GH-F, et al. Cigarette smoking hinders human periodontal ligament-derived stem cell proliferation, migration and differentiation potentials. Sci Rep. 2015;5:7828.

53. Heikinheimo K, Kurppa KJ, Laiho A, Peltonen S, Berdal A, Bouattour A, et al. Early dental epithelial transcription factors distinguish Ameloblastoma from Keratocystic odontogenic tumor. J Dent Res. 2015;94:101-11.

54. Davanian $H$, Balasiddaiah A, Heymann R, Sundström M, Redenström $P$, Silfverberg $M$, et al. Ameloblastoma RNA profiling uncovers a distinct noncoding RNA signature. Oncotarget. 2017:8:4530-42.

55. Kim J-H, Jeon M, Song J-S, Lee J-H, Choi B-J, Jung H-S, et al. Distinctive genetic activity pattern of the human dental pulp between deciduous and permanent teeth. PLoS One. 2014;9:e102893.

56. Simmer JP, Richardson AS, Wang S-K, Reid BM, Bai Y, Hu Y, et al. Ameloblast transcriptome changes from secretory to maturation stages. Connect Tissue Res. 2014;55:29-32.

57. Zhai $Y$, Wei R, Liu J, Wang H, Cai W, Zhao M, et al. Drug-induced premature senescence model in human dental follicle stem cells. Oncotargetlmpact Journals, LLC. 2017;8:7276-93.

58. Nizamuddin S, Govindaraj P, Saxena S, Kashyap M, Mishra A, Singh S, et al. A novel gene THSD7A is associated with obesity. Int J Obes (Lond). 2015;39:1662-5.

59. Gay I, Cavender A, Peto D, Sun Z, Speer A, Cao H, et al. Differentiation of human dental stem cells reveals a role for microRNA-218. J Periodontal ResNIH Public Access. 2014;49:110-20.

60. Aker M, Rouvinski A, Hashavia S, Ta-Shma A, Shaag A, Zenvirt S, et al. An SNX10 mutation causes malignant osteopetrosis of infancy. J Med Genet. 2012;49:221-6.

61. Stattin E-L, Henning P, Klar J, McDermott E, Stecksen-Blicks C, Sandstrom P$E$, et al. SNX10 gene mutation leading to osteopetrosis with dysfunctional osteoclasts. Sci Rep. 2017;7:3012.

62. Smith SB, Maixner DW, Greenspan JD, Dubner R, Fillingim RB, Ohrbach R, et al. Potential genetic risk factors for chronic TMD: genetic associations from the OPPERA case control study. J PainNIH Public Access. 2011;12:T92-101.

63. Cobourne MT, Xavier GM, Depew M, Hagan L, Sealby J, Webster Z, et al. Sonic hedgehog signalling inhibits palatogenesis and arrests tooth development in a mouse model of the nevoid basal cell carcinoma syndrome. Dev BiolElsevier. 2009;331:38-49.

64. Haas R, Smith J, Rocher-Ros V, Nadkarni S, Montero-Melendez T, D'Acquisto $F$, et al. Lactate regulates metabolic and pro-inflammatory circuits in control of T cell migration and effector functions. PLoS Biol. 2015;13:e1002202.

65. Kemp JP, Medina-Gomez C, Estrada K, St Pourcain B, Heppe DHM, Warrington NM, et al. Phenotypic dissection of bone mineral density reveals skeletal site specificity and facilitates the identification of novel loci in the genetic regulation of bone mass attainment. PLoS GenetPublic Library of Science. 2014;10:e1004423.
66. Yamakami Y, Kohashi K, Oyama K, Mohri Y, Hidema S, Nishimori K. LGR4 is required for sequential molar development. Biochem Biophys Reports. 2016;8:174-83.

67. Lu Y, Day FR, Gustafsson S, Buchkovich ML, Na J, Bataille V, et al. New loci for body fat percentage reveal link between adiposity and cardiometabolic disease risk. Nat Commun. 2016;7:10495.

68. Willer CJ, Speliotes EK, Loos RJF, Li S, Lindgren CM, Heid IM, et al. Six new loci associated with body mass index highlight a neuronal influence on body weight regulation. Nat GenetEurope PMC Funders. 2009;41:25-34.

69. Su Y, Fan Z, Wu X, Li Y, Wang F, Zhang C, et al. Genome-wide DNA methylation profile of developing deciduous tooth germ in miniature pigs. BMC GenomicsBioMed Central. 2016;17:134.

70. Liu C, Niu Y, Zhou X, Xu X, Yang Y, Zhang Y, et al. Cell cycle control, DNA damage repair, and apoptosis-related pathways control pre-ameloblasts differentiation during tooth development. BMC GenomicsBioMed Central. 2015;16:592.

71. Devic I, Shi M, Schubert MM, Lloid M, Izutsu KT, Pan C, et al. Proteomic analysis of saliva from patients with oral chronic graft-versus-host disease. Biol Blood Marrow TransplantNIH Public Access. 2014;20:1048-55.

72. Heino M, Peterson P, Kudoh J, Shimizu N, Antonarakis SE, Scott HS, et al. APECED mutations in the autoimmune regulator (AIRE) gene. Hum Mutat. 2001;18:205-11.

73. Liu X, Cotrim A, Teos L, Zheng C, Swaim W, Mitchell J, et al. Loss of TRPM2 function protects against irradiation-induced salivary gland dysfunction. Nat Commun. 2013;4:1515.

74. Peled A, Sarig O, Samuelov L, Bertolini M, Ziv L, Weissglas-Volkov D, et al. Mutations in TSPEAR, encoding a regulator of notch signaling, affect tooth and hair follicle morphogenesis. PLoS Genet. 2016;12:e1006369.

75. Yong-Deok K, Eun-Hyoung J, Yeon-Sun K, Kang-Mi P, Jin-Yong L, SungHwan C, et al. Molecular genetic study of novel biomarkers for early diagnosis of oral squamous cell carcinoma. Med Oral Patol Oral Cir BucalMedicina Oral S.L. 2015;20:e167-79.

76. Baumann M, Giunta C, Krabichler B, Rüschendorf F, Zoppi N, Colombi M, et al. Mutations in FKBP14 cause a variant of Ehlers-Danlos syndrome with progressive kyphoscoliosis, myopathy, and hearing loss. Am J Hum GenetElsevier. 2012;90:201-16.

77. Abel MD, Carrasco LR. Ehlers-Danlos syndrome: classifications, oral manifestations, and dental considerations. Oral Surg Oral Med Oral Pathol Oral Radiol EndodWB Saunders, Philadelphia. 2006;102:582-90.

78. Lee $Y-Y$, Chan $C-H$, Hung S-L, Chen Y-C, Lee Y-H, Yang S-F. Up-regulation of nucleotide-binding oligomerization domain 1 in inflamed human dental pulp. J Endod. 2011;37:1370-5.

79. Okugawa T, Kaneko T, Yoshimura A, Silverman N, Hara Y. NOD1 and NOD2 mediate sensing of periodontal pathogens. J Dent Res. 2010;89:186-91.

80. Liu J, Duan J, Wang Y, Ouyang X. Intracellular adhesion Molecule-1 is regulated by Porphyromonas gingivalis through nucleotide binding oligomerization domain-containing proteins 1 and 2 molecules in periodontal fibroblasts. J Periodontol. 2014;85:358-68.

81. Jiao Y, Darzi Y, Tawaratsumida K, Marchesan JT, Hasegawa M, Moon H, et al. Induction of bone loss by Pathobiont-mediated Nod1 signaling in the Oral cavity. Cell Host Microbe. 2013;13:595-601.

82. Patel VN, Lombaert IMA, Cowherd SN, Shworak NW, Xu Y, Liu J, et al. Hs3st3-modified heparan sulfate controls KIT+ progenitor expansion by regulating 3-O-sulfotransferases. Dev CellNIH Public Access. 2014;29:662-73.

83. Lessel D, Hisama FM, Szakszon K, Saha B, Sanjuanelo AB, Salbert BA, et al. POLD1 germline mutations in patients initially diagnosed with Werner syndrome. Hum MutatNIH Public Access. 2015;36:1070-9.

84. EL Smith C, LE Whitehouse L, Poulter JA, Brookes SJ, Day PF, Soldani F, et al. Defects in the acid phosphatase ACPT cause recessive hypoplastic amelogenesis imperfecta. Eur J Hum Genet. 2017;25:1015-9.

85. Blanchard AA, Ezzati P, Shamshurin D, Nistor AC, Leygue E, Wilkins JA, et al. Towards further defining the proteome of mouse saliva. Proteome SciBioMed Central. 2015;13:10.

86. Yiu WH, Wong DWL, Chan LYY, Leung JCK, Chan KW, Lan HY, et al. Tissue Kallikrein mediates pro-inflammatory pathways and activation of proteaseactivated Receptor-4 in proximal tubular epithelial cells. PLoS One. 2014;9:e88894.

87. Hart PS, Hart TC, Michalec MD, Ryu OH, Simmons D, Hong S, et al. Mutation in kallikrein 4 causes autosomal recessive hypomaturation amelogenesis imperfecta. J Med Genet. 2004;41:545-9.

88. Higuchi H, Shoji T, lijima S, Nishijima K. Constitutively expressed Siglec-9 inhibits LPS-induced CCR7, but enhances IL-4-induced CD200R expression in human macrophages. Biosci Biotechnol Biochem. 2016;80:1141-8. 
89. Schwarz F, Springer SA, Altheide TK, Varki NM, Gagneux P, Varki A. Humanspecific derived alleles of CD33 and other genes protect against postreproductive cognitive decline. Proc Natl Acad Sci U S ANational Academy of Sciences. 2016;113:74-9.

90. Olszak T, Neves JF, Dowds CM, Baker K, Glickman J, Davidson NO, et al. Protective mucosal immunity mediated by epithelial CD1d and IL-10. Nature. 2014;509:497-502.

91. Kulkarni G, Sakki EP, Kumar W, Kolimi S, Perika R, Karthik KV, et al. Expression of CD1a by Langerhan's cells in Oral lichen planus - a retrospective analysis. J Clin Diagn ResJCDR Research \& Publications Private Limited. 2016;10:ZC28-31.

92. Dutzan N, Konkel JE, Greenwell-Wild T, Moutsopoulos NM. Characterization of the human immune cell network at the gingival barrier. Mucosal ImmunoINature Publishing Group. 2016;9:1163-72.

93. Olender $T$, Lancet $D$, Nebert DW. Update on the olfactory receptor (OR) gene superfamily. Hum GenomicsBioMed Central. 2008;3:87-97.

94. Broz P, Monack DM. Molecular mechanisms of inflammasome activation during microbial infections. Immunol RevNIH Public Access. 2011;243:174-90.

95. Torgerson DG, Ampleford E, Chiu GY, Gauderman WJ, Gignoux CR, Graves PE, et al. Meta-analysis of genome-wide association studies of asthma in ethnically diverse north American populations. Nat GenetNIH Public Access. 2011;43:887-92.

96. Michon F, Tummers M, Kyyrönen M, Frilander MJ, Thesleff I. Tooth morphogenesis and ameloblast differentiation are regulated by micro-RNAs. Dev Biol. 2010;340:355-68.

97. Bebek G, Bennett KL, Funchain P, Campbell R, Seth R, Scharpf J, et al. Microbiomic subprofiles and MDR1 promoter methylation in head and neck squamous cell carcinoma. Hum Mol GenetOxford University Press. 2012;21: $1557-65$.

98. Volkmann BA, Zinkevich NS, Mustonen A, Schilter KF, Bosenko DV, Reis LM, et al. Potential novel mechanism for Axenfeld-Rieger syndrome: deletion of a distant region containing regulatory elements of PITX2. Investig Opthalmology Vis Sci. 2011;52:1450.

99. Hollink IH, Alfadhel M, Al-Wakeel AS, Ababneh F, Pfundt R, de Man SA, et al. Broadening the phenotypic spectrum of pathogenic LARP7 variants: two cases with intellectual disability, variable growth retardation and distinct facial features. J Hum Genet. 2016;61:229-33.

100. Kang $\mathrm{I}-\mathrm{H}$, Jeong B-C, Hur S-W, Choi H, Choi S-H, Ryu J-H, et al. MicroRNA302a stimulates osteoblastic differentiation by repressing COUP-TFII expression. J Cell Physiol. 2015;230:911-21.

101. Takeuchi H, Takada A, Kuboniwa M, Amano A. Intracellular periodontal pathogen exploits recycling pathway to exit from infected cells. Cell Microbiol. 2016;18:928-48.

102. Watanabe $T$, Oyama T, Asada M, Harada $D$, Ito $Y$, Inagawa $M$, et al. MAML1 enhances the transcriptional activity of Runx2 and plays a role in bone development. PLoS GenetPublic Library of Science. 2013;9:e1003132.

103. Davanian H, Stranneheim H, Bage T, Lagervall M, Jansson L, Lundeberg J, et al. Gene expression profiles in paired gingival biopsies from periodontitisaffected and healthy tissues revealed by massively parallel sequencing. PLoS OnePublic Library of Science. 2012;7:e46440.

104. De Coster PJ, Cornelissen M, De Paepe A, Martens LC, Vral A. Abnormal dentin structure in two novel gene mutations [COL1A1, Arg134Cys] and [ADAMTS2, Trp795-to-ter] causing rare type I collagen disorders. Arch Oral Biol. 2007;52:101-9.

105. Paulissen G, Rocks N, Gueders MM, Crahay C, Quesada-Calvo F, Bekaert S, et al. Role of ADAM and ADAMTS metalloproteinases in airway diseases. Respir Res. 2009;10:127.

106. Du A, Zhao S, Wan L, Liu T, Peng Z, Zhou Z, et al. MicroRNA expression profile of human periodontal ligament cells under the influence of Porphyromonas gingivalis LPS. J Cell Mol Med. 2016;20:1329-38.

107. Offenbacher S, Divaris K, Barros SP, Moss KL, Marchesan JT, Morelli T, et al. Genome-wide association study of biologically informed periodontal complex traits offers novel insights into the genetic basis of periodontal disease. Hum Mol GenetOxford University Press. 2016;25:2113-29.

108. Laugel-Haushalter V, Paschaki M, Thibault-Carpentier C, Dembelé D, Dollé P, Bloch-Zupan A. Molars and incisors: show your microarray IDs. BMC Res NotesBioMed Central. 2013;6:113.

109. Shroff B, Kashner JE, Keyser JD, Hebert C, Norris K. Epidermal growth factor and epidermal growth factor-receptor expression in the mouse dental follicle during tooth eruption. Arch Oral Biol. 1996;41:613-7.

110. Arai C, Yoshizaki K, Miyazaki K, Saito K, Yamada A, Han X, et al. Nephronectin plays critical roles in Sox2 expression and proliferation in dental epithelial stem cells via EGF-like repeat domains. Sci Rep. 2017;7:45181.
111. Mahendra A, Shreedhar B, Kamboj M, Singh A, Singh A, Agrawal A, et al. Epidermal growth factor receptor protein: a biological marker for Oral Precancer and cancer. J Dent SurgHindawi. 2014;2014:1-7.

112. Zeldich $E$, Koren R, Dard M, Nemcovsky C, Weinreb M. EGFR in enamel matrix derivative-induced gingival fibroblast Mitogenesis. J Dent Res. 2008;87:850-5.

113. Zhang B, Khalaf H, Sirsjö A, Bengtsson T. Gingipains from the periodontal pathogen Porphyromonas gingivalis play a significant role in regulation of angiopoietin 1 and angiopoietin 2 in human aortic smooth muscle cells. Infect Immun. 2015;83:4256-65.

114. Ozturk A, Famili P, Vieira AR. The antimicrobial peptide DEFB1 is associated with caries. J Dent Res. 2010;89:631-6.

115. Navarra CO, Robino A, Pirastu N, Bevilacqua L, Gasparini P, Di Lenarda R, et al. Caries and innate immunity: DEFB1 gene polymorphisms and caries susceptibility in genetic isolates from North-Eastern Italy. Caries Res. 2016;50:589-94.

116. Winter J, Pantelis A, Kraus D, Reckenbeil J, Reich R, Jepsen S, et al. Human adefensin (DEFA) gene expression helps to characterise benign and malignant salivary gland tumours. BMC CancerBioMed Central. 2012;12:465.

117. Sun CQ, Arnold R, Fernandez-Golarz C, Parrish AB, Almekinder T, He J, et al. Human $\beta$-Defensin-1, a potential chromosome $8 p$ tumor suppressor: control of transcription and induction of apoptosis in renal cell carcinoma. Cancer Res. 2006;66:8542-9.

118. Wang Q, Cai J, Cai X-H, Chen L. miR-346 regulates osteogenic differentiation of human bone marrow-derived mesenchymal stem cells by targeting the Wnt/ $\beta$-catenin pathway. PLoS OnePublic Library of Science. 2013;8:e72266.

119. Yin K, Hacia JG, Zhong Z, Paine ML. Genome-wide analysis of miRNA and mRNA transcriptomes during amelogenesis. BMC Genomics. 2014;15:998.

120. Lyssenko V, Nagorny CLF, Erdos MR, Wierup N, Jonsson A, Spégel P, et al. Common variant in MTNR1B associated with increased risk of type 2 diabetes and impaired early insulin secretion. Nat Genet. 2009;41:82-8.

121. Magnucki G, Schenk U, Ahrens S, Navarrete Santos A, Gernhardt CR, Schaller $\mathrm{H}-\mathrm{G}$, et al. Expression of the IGF-1, IGFBP-3 and IGF-1 receptors in dental pulp stem cells and impacted third molars. J Oral Sci. 2013;55:319-27.

122. Ohazama A, Sharpe PT. Expression of claudins in murine tooth development. Dev DynWiley-Liss, Inc. 2007;236:290-4.

123. Berndt SI, Gustafsson S, Magi R, Ganna A, Wheeler E, Feitosa MF, et al. Genome-wide meta-analysis identifies 11 new loci for anthropometric traits and provides insights into genetic architecture. Nat Genet. 2013;45:501-12.

124. Luukko K, Ylikorkala A, Mäkelä TP. Developmentally regulated expression of Smad3, Smad4, Smad6, and Smad7 involved in TGF-beta signaling. Mech Dev. 2001;101:209-12.

125. Wen W, Cho Y-S, Zheng W, Dorajoo R, Kato N, Qi L, et al. Meta-analysis identifies common variants associated with body mass index in east Asians. Nat GenetNIH Public Access. 2012;44:307-11.

126. Shen S, Huang D, Feng G, Zhu L, Zhang Y, Cao P, et al. MEF2 transcription factor regulates osteogenic differentiation of dental pulp stem cells. Cell ReprogramMary Ann Liebert, Inc. 140 Huguenot Street, 3rd Floor New Rochelle, NY 10801 USA. 2016;18:237-45.

127. Han X, Amar S. Role of insulin-like growth Factor-1 signaling in dental fibroblast apoptosis. J Periodontol. 2003;74:1176-82.

128. Karim Z, Gérard B, Bakouh N, Alili R, Leroy C, Beck L, et al. NHERF1 mutations and responsiveness of renal parathyroid hormone. N Engl J Med. 2008;359:1128-35.

129. Salvi A, Giacopuzzi E, Bardellini E, Amadori F, Ferrari L, De Petro G, et al. Mutation analysis by direct and whole exome sequencing in familial and sporadic tooth agenesis. Int J Mol MedSpandidos Publications. 2016;38:1338-48.

130. Bauer F, Elbers CC, Adan RA, Loos RJ, Onland-Moret NC, Grobbee DE, et al. Obesity genes identified in genome-wide association studies are associated with adiposity measures and potentially with nutrient-specific food preference. Am J Clin NutrAmerican Society for Nutrition. 2009;90:951-9.

131. Ebersole JL, Kirakodu S, Novak MJ, Exposto CR, Stromberg AJ, Shen S, et al. Effects of aging in the expression of NOD-like receptors and inflammasomerelated genes in oral mucosa. Mol Oral Microbiol. 2016;31:18-32.

132. Cheng S-J, Chang C-F, Lee J-J, Chen H-M, Wang H-J, Liou Y, et al. Hypermethylated ZNF582 and PAX1 are effective biomarkers for detection of oral dysplasia and oral cancer. Oral Oncol. 2016;62:34-43.

133. Fraser GJ, Bloomquist RF, Streelman JT. Common developmental pathways link tooth shape to regeneration. Dev Biol. 2013;377:399-414.

134. Rees SD, Hydrie MZI, O'Hare JP, Kumar S, Shera AS, Basit A, et al. Effects of 16 genetic variants on fasting glucose and type 2 diabetes in south Asians: ADCY5 and GLIS3 variants may predispose to type 2 diabetes. PLoS OnePublic Library of Science. 2011;6:e24710. 
135. Tuomi T, Nagorny CLF, Singh P, Bennet H, Yu Q, Alenkvist I, et al. Increased melatonin signaling is a risk factor for type 2 diabetes. Cell Metab. 2016;23:1067-77.

136. Wang Y, Tatakis DN. Human gingiva transcriptome during wound healing. J Clin Periodontol. 2017;44:394-402.

137. Rowland K, Kanive C, Wells J, Hatton J. TRPM2 immunoreactivity is increased in fibroblasts, but not nerves, of symptomatic human dental pulp. J Endod. 2007;33:245-8.

138. Liu X, Gong B, De Souza LB, et al. Radiation inhibits salivary gland function by promoting STIM1 cleavage by caspase-3 and loss of SOCE through a TRPM2-dependent pathway. Sci Signal. 2017;10(482). https://doi.org/10. 1126/scisignal.aal4064.

139. Everson JL, Fink DM, Yoon JW, Leslie EJ, Kietzman HW, Ansen-Wilson LJ, et al. Sonic hedgehog regulation of Foxf2 promotes cranial neural crest mesenchyme proliferation and is disrupted in cleft lip morphogenesis. Development. 2017;144:2082-91.

140. Aitola M, Carlsson P, Mahlapuu M, Enerback S, Pelto-Huikko M. Forkhead transcription factorFoxF2 is expressed in mesodermal tissues involved in epithelio-mesenchymal interactions. Dev Dyn. 2000;218:136-49.

141. Ganz T. Defensins: antimicrobial peptides of innate immunity. Nat Rev Immunol. 2003;3:710-20.

142. Merchant AT. Periodontitis and dental caries occur together. J Evid Based Dent Pract. 2012;12(3 Suppl):18-9. https://doi.org/10.1016/S15323382(12)70005-2

143. Alavaikko S, Jaakkola MS, Tjaderhane L, Jaakkola JJK. Asthma and caries: a systematic review and meta-analysis. Am J Epidemiol. 2011;174:631-41.

144. Ballantine JL, Carlson JC, Ferreira Zandoná AG, et al. Exploring the genomic basis of early childhood caries: a pilot study. Int J Paediatr Dent. 2018;28(2): 217-25. https://doi.org/10.1111/ipd.12344.

145. Childers NK, Grenett H, Morrow C, Kumar R, Jezewski PA. Potential risk for localized aggressive periodontitis in African American preadolescent children. Pediatr DentNIH Public Access. 2017;39:294-8.

146. Campbell MC, Tishkoff SA. African genetic diversity: implications for human demographic history, modern human origins, and complex disease mapping. Annu Rev Genomics Hum Genet. 2008;9:403-33.

147. Nelson SC, Doheny KF, Pugh EW, Romm JM, Ling H, Laurie CA, et al. Imputation-based genomic coverage assessments of current human genotyping arrays. G3. 2013;3:1795-807.

148. Services USDoHaH. The Secretary's advisory committee on National Health Promotion and disease prevention objectives for 2020. Washington, D.C. [cited 2017 Aug 11]. Available from: https://www.healthypeople.gov/

149. Sankar PL, Parker LS. The precision medicine initiative's all of us Research Program: an agenda for research on its ethical, legal, and social issues. Genet Med. 2017;19(7):743-50. https://doi.org/10.1038/gim.2016.183.

\section{Publisher's Note}

Springer Nature remains neutral with regard to jurisdictional claims in published maps and institutional affiliations.

Ready to submit your research? Choose BMC and benefit from:

- fast, convenient online submission

- thorough peer review by experienced researchers in your field

- rapid publication on acceptance

- support for research data, including large and complex data types

- gold Open Access which fosters wider collaboration and increased citations

- maximum visibility for your research: over $100 \mathrm{M}$ website views per year

At $\mathrm{BMC}$, research is always in progress.

Learn more biomedcentral.com/submissions 